\title{
Trends in flash flood events versus convective precipitation in the Mediterranean region: The case of Catalonia
}

\author{
Maria Carmen Llasat ${ }^{\mathrm{a}, *}$, Raul Marcos ${ }^{\mathrm{b}}$, Marco Turco ${ }^{\mathrm{b}}$, Joan Gilabert ${ }^{\mathrm{a}}$, Montserrat Llasat-Botija ${ }^{\mathrm{a}}$ \\ ${ }^{a}$ Dept. Astronomy and Meteorology, University of Barcelona, Barcelona, Spain \\ barcelona Supercomputing Center - Centro Nacional de Supercomputación (BSC-CNS), Barcelona, Spain
}

\section{A R T I C L E I N F O}

\section{Article history:}

Available online 27 May 2016

\section{Keywords:}

Flash floods

Convective precipitation

$\beta$ parameter

Trend analysis

Mediterranean

\begin{abstract}
S U M M A R Y
The aim of this paper is to analyse the potential relationship between flash flood events and convective precipitation in Catalonia, as well as any related trends. The paper starts with an overview of flash floods and their trends in the Mediterranean region, along with their associated factors, followed by the definition of, identification of, and trends in convective precipitation. After this introduction the paper focuses on the north-eastern Iberian Peninsula, for which there is a long-term precipitation series (since 1928) of 1-min precipitation from the Fabra Observatory, as well as a shorter (1996-2011) but more extensive precipitation series (43 rain gauges) of 5-min precipitation. Both series have been used to characterise the degree of convective contribution to rainfall, introducing the $\beta$ parameter as the ratio between convective precipitation versus total precipitation in any period. Information about flood events was obtained from the INUNGAMA database (a flood database created by the GAMA team), with the aim of finding any potential links to convective precipitation. These flood data were gathered using information on damage where flood is treated as a multifactorial risk, and where any trend or anomaly might have been caused by one or more factors affecting hazard, vulnerability or exposure. Trend analysis has shown an increase in flash flood events. The fact that no trends were detected in terms of extreme values of precipitation on a daily scale, nor on the associated ETCCDI (Expert Team on Climate Change Detection and Indices) extreme index, could point to an increase in vulnerability, an increase in exposure, or changes in land use. However, the summer increase in convective precipitation was concentrated in less torrential events, which could partially explain this positive trend in flash flood events. The $\beta$ parameter has been also used to characterise the type of flood event according to the features of the precipitation. The highest values correspond to short and local events, usually with daily $\beta$ values above 0.5 , while the minimum threshold of daily $\beta$ for catastrophic flash floods is 0.31 .
\end{abstract}

\section{Introduction}

Although there is no single definition, a flash flood is usually defined as a sudden flood in a small catchment area (usually less than $1000 \mathrm{~km}^{2}$ ), occurring within $6 \mathrm{~h}$ or less of the causative event (heavy rain, dam break, levee failure, rapid snowmelt or glacieroutburst flood) and often within $2 \mathrm{~h}$ of the start of high intensity rainfall (see www.nws.noaa.gov; for an in-depth analysis of the term "flash floods" see Gaume and Borga, 2008; Borga et al., 2008; Braud et al., 2014). Flash floods are usually caused by heavy rainfall that can either be local, affecting only one or two catchments, or more extended, producing flash floods as part of the framework of a major flood event.

\footnotetext{
* Corresponding author at: Faculty of Physics, University of Barcelona, Martí i Franqués 1, 08028 Barcelona, Spain.

E-mail address: carmell@am.ub.es (M.C. Llasat).
}

The Mediterranean region is prone to flash floods, especially in the north-west (Jansà et al., 2014), where littoral and pre-littoral mountain chains favour not only torrential rain concentrated in small catchments, but also heavy rainfall. The short concentration times and the extraordinary runoffs that develop can turn into catastrophic flash floods like those that occurred on 25 September 1962 in northeastern Spain, when 815 people died in less than $5 \mathrm{~h}$ (Aulet et al., 2012; Gaume et al., 2009). There are several studies in the literature showing a deeper analysis of specific flash floods in this region, such as the November 2011 case in Genoa, Italy (Fiori et al., 2014); the September 2002 event in the Gard Region, France (Delrieu et al. 2005; Braud et al., 2010; Milelli et al., 2006); and the June 2000 event in Montserrat, Spain (Martín et al., 2007; Milelli et al., 2006). Other works cover flash flood inventories in Europe, such as the article by Gaume et al. (2009) that analyses peak flash flood distributions for seven European regions; the study on flood response time for 25 extreme flash 
floods by Marchi et al. (2010); and the article by Garambois et al. (2014) on the study of flash flood-triggering storms and the resulting hydrological responses for catchments in the Aude region, France.

Most of these studies are focused on hydrological and hydrometeorological modelling, applying the most suitable distributed hydrological models for this kind of event, such as the RIBS (Real Interactive Basin Simulator, Garrote and Bras, 1995a, 1995b), DRiFt (Discharge River Forecast, Giannoni et al., 2000) and HVB (Hydrologiska Byråns Vattenbalansavdelning model, Lindstrom et al., 1997). In these cases the input was provided using sophisticated mesoscale meteorological models such as AROME (Applications of Research to Operations at Mesoscale model, Seity et al., 2011), WRF (Weather Research and Forecasting model, Skamarock et al., 2005) and MESO-NH (Non-Hydrostatic Mesoscale atmospheric model, Lafore et al., 1998), or using a combination of rain gauges and meteorological radar data (Atencia et al., 2011). The recently finished EU funded project DRIHM (Distributed Research Infrastructure for Hydro-Meteorology), was specifically focused on using grid computer facilities to create a Meteorological Model Bridge (MMB) to develop the interoperability of these meteorological and hydrological models, and it was applied to the recent flash floods recorded in Genoa in 2011 and 2014 (Fiori et al., 2014; Hally et al., 2015) and in Catalonia in 2011 (Llasat et al., 2015). However, in spite of the notable improvements achieved over the last few years, modelling high-intensity rainfall associated with convective precipitation is still a major challenge.

Convective precipitation (strictly precipitation associated with convective clouds), can be identified from weather radar imagery (e.g. Rigo and Llasat, 2004), or from new satellite products such as those developed by the Eumetsat Network for Satellite Applications and Facilities (SAF) (http://hsaf.meteoam.it/). However, it is not usually recorded as such and is therefore not identified on climatological records. Only when long term series of rainfall hydrographs are available is it possible to identify convective precipitation through visual inspection and digitisation (Puigcerver et al., 1986). In order to resolve this problem, some authors have identified convective precipitation with thunderstorms (e.g. Rice and Holmberg, 1973). More frequently, a threshold is used that establishes the minimum value below which rainfall is not considered convective (e.g. Dutton and Dougherty, 1979). Llasat (2001) proposed a classification for pluviometric episodes based on their convective nature. In order to do this the $\beta$ parameter was defined to show the contribution of convective precipitation to total precipitation, calculated on the basis of the surface rainfall intensity and considering the threshold of $1 \mathrm{~mm} / \mathrm{min}$ or $35 \mathrm{~mm} / \mathrm{h}$ to categorise convective precipitation into 1 -min or 5 -min precipitation series, respectively, following Eq. (1).

$\beta_{L, \Delta T}=\frac{\sum_{i=1}^{N} I\left(t_{i}, t_{i}+\Delta T\right) \theta(I-L)}{\sum_{i} I\left(t_{i}, t_{i}+\Delta T\right)}$

in which:

$\Delta T$ is the time-interval, expressed in minutes.

$N$ is the total number of $\Delta T$ integration steps into which the episode is subdivided.

$I\left(t_{i}, t_{i}+\Delta t\right)$ is the precipitation measured between $t_{i}$ and $t_{i}+\Delta t$ divided by $\Delta t$, that is, the mean intensity for said interval expressed in $\mathrm{mm} / \mathrm{min}$ or $\mathrm{mm} / \mathrm{h}$.

$\theta(I-L)$ is the Heaviside function defined as:

$\theta(I-L)=1$ if $I \geqslant L$

$\theta(I-L)=0$ if $I<L$

where $L=1 \mathrm{~mm} / \mathrm{min}$ when $\Delta T=1 \mathrm{~min}$, and $L=35 \mathrm{~mm} / \mathrm{min}$ when $\Delta T=5 \mathrm{~min}$.
The classification was corroborated afterwards using radar estimates (Llasat et al., 2007). Depending on the contribution of convective precipitation to total precipitation, $\beta$, recorded in the selected period (rainfall episode, meteorological event producing rainfall, daily, monthly or yearly period), the rainfall events or sub-events can be classified as follows (Llasat, 2001):

\section{$0 . \beta=0$ non-convective}

1. $0<\beta<0.3$ slightly convective

2. $0.3<\beta<0.8$ moderately convective

3. $0.8<\beta<1.0$ strongly convective

From a climate perspective, thunderstorms and showers, both of convective origin, are usually produced in summer and early autumn, because they are favoured by low level instability and high temperatures. In the Mediterranean region, summer events are usually local and of short duration, while in the autumn, the warmer sea surface temperature, as well as the large number of cyclones and organised perturbations, can give rise to extended catastrophic flash flood events (Jansà et al., 2001, 2014). Although it is not always possible to distinguish between floods and flash floods, their intra-annual variation peaks between August and December in the north-west Mediterranean. This can be seen in the analysis carried out during the HYMEX project, looking at 385 floods that occurred between 1981 and 2010 in north-east Spain, south-east France and south-west Italy (Llasat et al., 2013). In the case of Catalonia, flash floods are concentrated between August and October, which is consistent with the distribution of convective precipitation (Llasat, 2001; Llasat et al., 2014). Although catastrophic events mainly occur in the autumn, like the floods of 25 September 1962 and 7 November 1982, some catastrophic flash floods take place in the summer, like the flash flood event of 31 July 2002 and the most recent flood event of 18 June 2013. Other articles, like the one by Papagiannaki et al. (2013) for Greece, also show that rainfall during the summer-autumn period is the most significant for causing flash floods.

In this context, some authors state the difficulty of estimating intra-annual and inter-annual flash flood distribution, and, consequently, the difficulty in ascertaining trends and potential causes. The fact that a great number of these events take place in ungauged catchments and, at the same time, the unavailability of long-term precipitation series on rainfall intensity, makes it difficult to analyse both flow and heavy rainfall series Usually, trends are calculated using flood data series compiled from damages and impact assessments (i.e. Barrera-Escoda and Llasat, 2015; Llasat et al., 2005; McDonald, 2014) or from other proxy data like tax records (i.e. Brazdil et al., 2014), and, consequently, they refer to the flood as a multifactorial risk, where any trend or anomaly might be caused by a change in one or more factors affecting the hazard, vulnerability or exposure. Authors such as Merz et al. (2012) and Hall et al. (2014) deal with this question in depth. Despite these difficulties, the analysis of the longest available flow series across Europe, recently published by Mediero et al. (2015), points to a clustering trend for flood rich and flood poor periods, where the term "flood" is based on proposed flow thresholds, independently of the damage produced. This kind of clustering is also found when the flood data series is obtained using historical data or proxy data are analysed. This is the case in the recent works by McDonald (2014) on floods in Great Britain over the last millennia, and by Barrera-Escoda and Llasat (2015) on floods in Catalonia (northeast Spain) over the last 600 years. In this sense, regional statistical tools are more powerful and more efficient when detecting trends (Sun et al., 2015). Madsen et al. (2014) reported "some evidence of a general increase of extreme precipitation whereas there are no clear indications of significant trends at large-scale regional or national level of extreme streamflow" in Europe. Mediero et al. 
(2015) observe that decreasing trends in flood magnitudes are shown in less than $35 \%$ of the classified catchments in the Atlantic and Continental European regions, mainly during the periods 1920-1999 and 1939-1998. Meanwhile, they detected a mixed pattern of changes in flood frequency, and very few significant changes in the timing of floods across all regions. This lack of a common or significant trend is a general result found in the majority of works dealing with flood time series analysis, as pointed out by the IPCC, both in their reports on Extremes (IPCC, 2012) and in the Fifth Report (IPCC, 2014). The IPCC concludes that there is "limited to medium" evidence available to assess climate-driven changes to the magnitude and frequency of floods on a regional scale, with "low agreement" evidence and "low confidence" on a global scale for signs of these changes.

When flow data are not available, floods are usually classified in terms of their impact (i.e. Glaser et al., 2010). In order to produce a classification that could be applied to the present and past results, most methodologies typically consider the degree of damage. In this paper we will use the same categories as those used in the framework of the European SPHERE project by Barriendos et al. (2003), later applied in papers by Llasat et al. (2005) and BarreraEscoda and Llasat (2015). Following this methodology, "Ordinary or small floods" (ORD) do not cause rivers to overflow their banks, cause some damage if activities are being carried out in or near the river at the time, and cause minor damage to hydraulic installations. "Extraordinary or intermediate floods" (EXT) are those that cause the rivers to overflow their banks, inconveniences to the daily life of the local population, and damage to structures near the river or stream, with possible partial destruction. "Catastrophic or large floods" (CAT) cause the rivers to overflow their banks and lead to serious damage or the destruction of hydraulic installations, infrastructure, paths and roadways, buildings, livestock, crops, and so on.

While there is no trend in catastrophic floods in Catalonia, extraordinary floods have increased with increasing time. Previous works associate these floods to changes in preventive measures, usually structural (e.g. Barrera et al., 2006) measures, changes in land use (e.g. ACA, 2009), or changes in exposure and vulnerability (e.g. Llasat et al., 2014), due to the fact that no trend has been observed in terms of extreme daily precipitation. However, no studies have been carried out analysing precipitation on a subdaily scale for the entire region and studying trends and potential relationships with flood events, until now. This is particularly relevant given that the majority of the flood events that affect Catalonia produce one or more flash floods, due to the topographical features of the basins and the characteristics of the associated precipitation. In this context, the main objective of this paper is to determine any possible relationship between convective precipitation and floods, and the respective trends.

The paper is organised as follows. Section 2 describes the study zone, data analysed and the methodology followed for the trend analysis. Section 3 characterises flood events in Catalonia and identifies trends in these events through time, while Section 4 focuses on convective precipitation. Section 5 focuses on flash floods events and convective features. The paper ends with the conclusions drawn.

\section{Area of study, data and methodology}

The domain analysed in this study is known as the Internal Basins of Catalonia (around 16,000 $\mathrm{km}^{2}$ ), located in the north-east of the Iberian Peninsula (Fig. 1). The region is characterised by two mountain ranges very close to the Mediterranean Sea that run roughly parallel to the coastline (SE-NE direction): the Littoral Range (maximum altitude around $600 \mathrm{MASL}$ ) and the Pre-littoral Range (maximum altitude around $1800 \mathrm{MASL}$ ). The Pyrenees are located in the north of the region, on the border with France, mainly running from west to east, with altitudes over than $2000 \mathrm{~m}$. This steep orography is crucial to the development of flash floods, both from a hydrological point of view (small torrential catchments) and from a meteorological point of view (i.e. orographic forcing of Mediterranean air mass) (Llasat and Puigcerver, 1992). In fact, the impact of the mountains on low level wind circulation usually triggers convective instability and affects the pressure fields, generating mesoscale circulations such as orographic dipoles, mesoscale lows and convergence lines (Jansà et al., 2014). Consequently, this region experiences thunderstorms and flash floods every year (Llasat et al., 2014).

To analyse convective precipitation, precipitation series with hourly or minute by minute data are needed. Forty-three stations from the SAIH (Automatic Hydrological Information System) network belonging to the Catalan Water Agency (Fig. 2), providing 5-min rainfall data, were selected due to their common data collecting period of 15 years (1996-2011). Four of them were also selected for a detailed analysis (plotted in red, Fig. 2). Boadella and Sau are located in the north-east, near two dams with the same names, respectively, that are both important for water resources (mainly agriculture and water supplies for cities) and flood management. Boadella (region R1) is situated in the Muga catchment (Table 1 ) in a very touristic region where agriculture
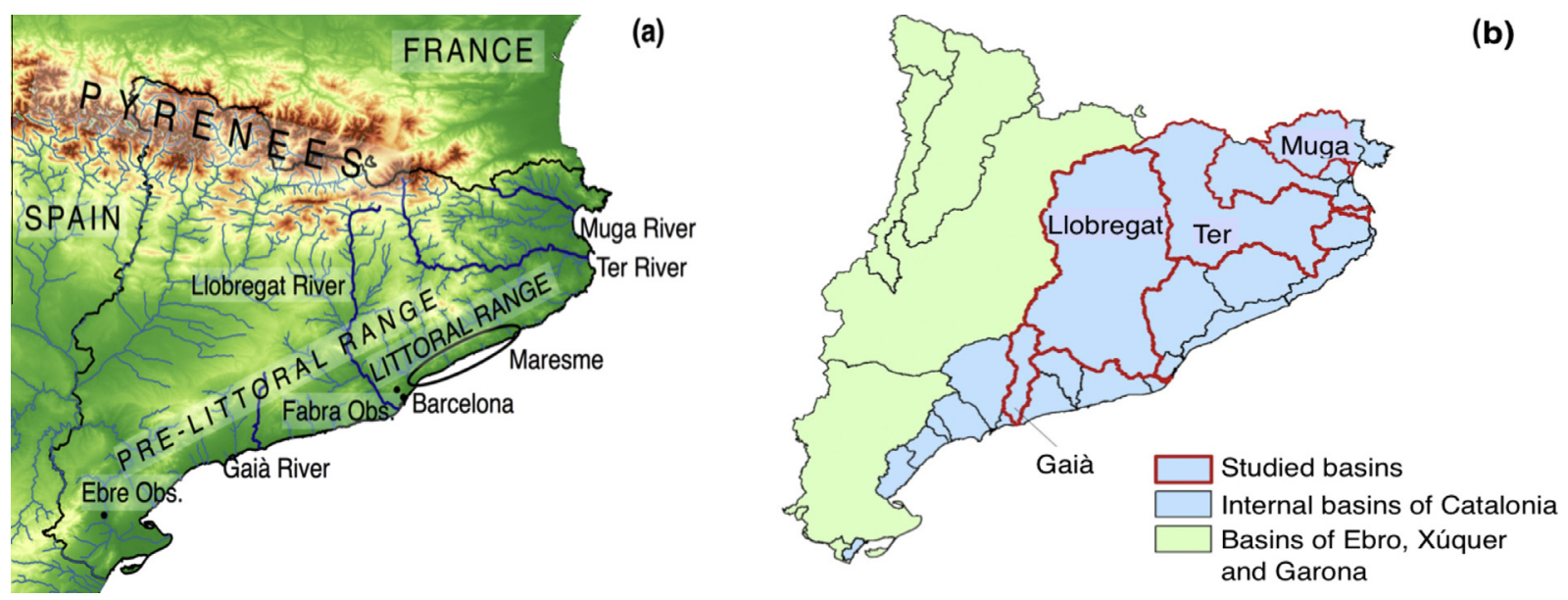

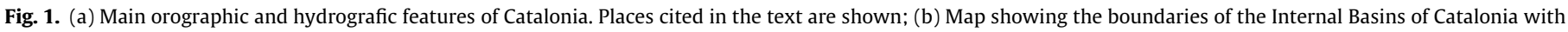
the selected catchments. 


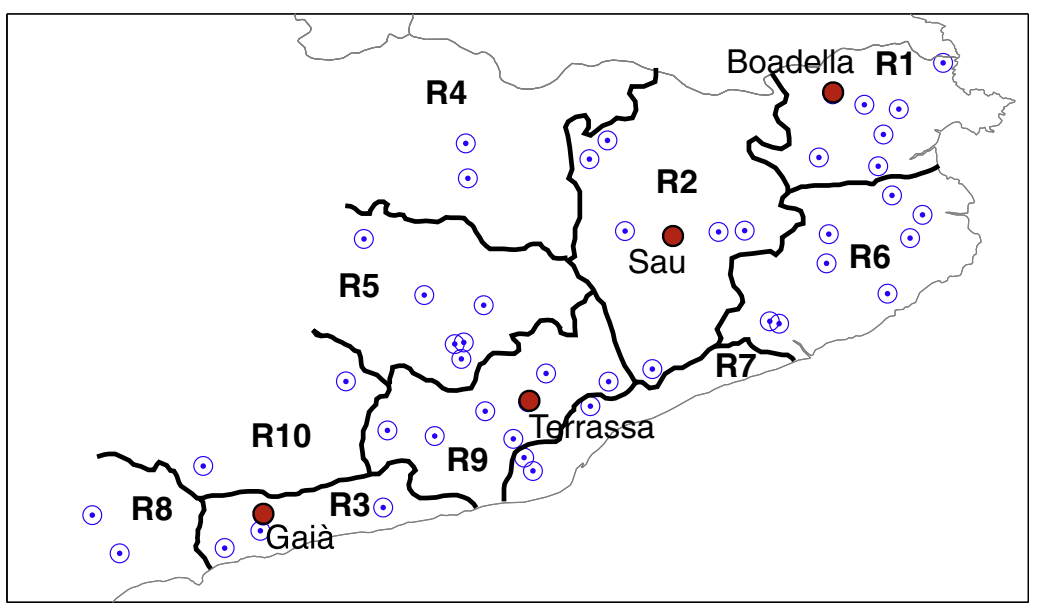

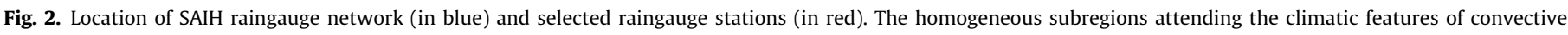

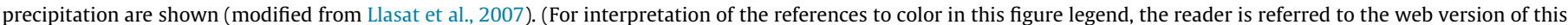
article.)

Table 1

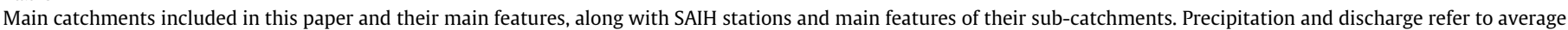
annual values. The Terrassa station is placed in the subcatchment of an ephemeral stream.

\begin{tabular}{|c|c|c|c|c|c|c|c|}
\hline Catchment & Size $\left(\mathrm{km}^{2}\right)$ & $P(\mathrm{~mm})$ & $Q\left(\mathrm{~m}^{3} / \mathrm{s}\right)$ & Gauge & Size $\left(\mathrm{km}^{2}\right)$ & $P(\mathrm{~mm})$ & $Q\left(\mathrm{~m}^{3} / \mathrm{s}\right)$ \\
\hline \multirow[t]{2}{*}{ Ter } & 3010 & 879 & 26.8 & Ripoll & 737 & 998 & 12.1 \\
\hline & & & & Sau & 1528 & 926 & 16.7 \\
\hline \multirow[t]{2}{*}{ Llobregat } & 4948 & 672 & 22.2 & Terrassa & 55 & 710 & 0 \\
\hline & & & & Martorell & 4577 & 703 & 20.8 \\
\hline Muga & 854 & 807 & 4.7 & Boadella & 181 & 892 & 2.0 \\
\hline Gaià & 424 & 519 & 0.8 & Gaià & 358 & 574 & 0.7 \\
\hline
\end{tabular}

is also important (Fig. 2). Sau (region R2) is placed in the Ter catchment (Table 1). This last river has experienced the highest flood frequency in Catalonia in the past, with 177 floods (22 catastrophic floods) in the period 1322-2002 (Llasat et al., 2005). Central and southern regions are represented by Terrassa (R7) and Gaià (R3). Terrassa is located in the most vulnerable part of Catalonia, where the population density, communication networks and industries are concentrated. It is crossed by some streams with a non-permanent water flow, but can also suffer catastrophic flash floods like those of September 1962, when, in this village, 400 people died or disappeared as a consequence of the flash flood in the Rubí river, which runs through the village. It is located in the Llobregat catchment (Table 1). Finally, the Gaià station is located in the southern part of the Internal Basins of Catalonia, and the Gaià River frequently suffers flash floods, such as the one in October 1994 (Table 1).

The study is complemented with the data series on rainfall rates for the Jardí rain gauge located in Barcelona (Fig. 1), at the Fabra Observatory (414 MASL). It operated continuously from 1927 to 1992, and was recalibrated in 2012. Although only the 1928-1977 period is homogeneous, it provides 50 years of data for a period that was largely unaffected by anthropogenic climatic change, and can be considered as a reference period (Turco et al. 2014). The raw data consists of daily charts on which each rainfall event is recorded in the form of a rainfall rate (ordinate) versus time (abscissa), including some observations such as the presence of a thunderstorm or wind (Puigcerver et al., 1986). All this information was digitised and used to analyse the statistical properties of the precipitation series as well as to characterise the contribution of convective precipitation to total precipitation (Llasat, 2001; Burgueño et al., 1987). 1-min and 5-min precipitation series were obtained and submitted to a very strict quality control and metadata analysis. The quality control for the 1-min and 5-min precipitation series consisted of checking for outliers (values exceeding five standard deviations), negative values and no-registers. All of these were reported as missing data and were not used for our calculations. After quality control, no month had more than $10 \%$ of missing data.

Flood trends were estimated from flood events. A flood event can be defined as any event during which one or more floods occur in one or more rivers, tributaries or streams, when any minor, moderate or major damage occurs. In this context, the generic word "flood" also includes flash floods. In the case of Catalonia the majority of flood events record one or more flash floods. In this work, catastrophic flood events were taken from the FLOODHYMEX database (Llasat et al., 2013) and updated until 2011, while extraordinary and ordinary flood events were taken from the INUNGAMA database (Llasat et al., 2014). Given that a flood event can affect more than one catchment, it is classified according to the worst damage associated with the flood, regardless of location.

The high-resolution $\left(0.2^{\circ} \times 0.2^{\circ}\right.$, approximately $\left.20 \mathrm{~km} \times 20 \mathrm{~km}\right)$ gridded dataset Spain02, (Herrera et al., 2012) for daily precipitation for the period 1951-2007, was also analysed in order to detect any possible trends on the ETCCDI (Expert Team on Climate Change Detection and Indices) indices related to precipitation. This dataset, which is publicly available for research activities at http://www. meteo.unican.es/datasets/spain02, was compiled using data from 2756 quality-controlled stations belonging to the Spanish Meteorological Agency (AEMET), covering the Spanish Iberian Peninsula and the Balearic Islands. An analysis of upper percentiles and extreme indicators revealed the capability of Spain02 to reproduce the intensity and spatial variability of extremes (Herrera et al., 
2012). The high quality of this dataset has also been confirmed by Turco and Llasat (2011) and has been used by Herrera et al. (2010) and Turco et al. (2011) respectively to validate and post-process the regional climate models (RCMs) generated by the ENSEMBLES project.

The trend significance is estimated using a circular block bootstrap procedure applied to non-normal distributions and autocorrelated series adapted by Turco and Llasat (2011). The practical implementation is summarised herein. First, this method decomposes the raw data into a linear trend line and a time series of residuals. Next, the residuals are resampled 1000 times and added back to the best fit line, obtaining 1000 new plausible trend estimations. Finally, the original trend significance is estimated considering whether the zero-trend falls outside the distribution of the 1000 plausible trend values. The computer code to implement this method is publicly available on the website http://www.am.ub.es/ $\sim$ mturco/codes/testTrend_MT.zip.

The trend analysis is applied to the annual and seasonal values for nine variables which might show an overall image of the evolution of precipitation in this region for the period 1996-2011: $\beta$, total precipitation, convective precipitation, precipitation with intensities above $35 \mathrm{~mm} / \mathrm{h}$, total precipitation time, convective precipitation time, precipitation time with intensities above $35 \mathrm{~mm} / \mathrm{h}$, number of convective precipitation days and number of convective precipitation episodes. Following the usual criteria (e.g. Turco and Llasat, 2011) we established a threshold of significance of $95 \%$.

\section{Floods and flash floods in Catalonia}

\subsection{Characterisation of flash floods in the selected region}

Basically, floods recorded in Catalonia can be classified under three main types:

- Type 1 or local flash floods (LFF): produced by short-lived events (less than $3 \mathrm{~h}$ and usually less than $1 \mathrm{~h}$ ) of very intense precipitation (peaks of 5 -min rainfall rate can be above $180 \mathrm{~mm} / \mathrm{h}$ ) but limited overall total rainfall $(<100 \mathrm{~mm})$. These local flash floods usually affect short, coastal, ephemeral and torrential watercourses (small catchments, 5-50 $\mathrm{km}^{2}$ ) and steep channels as well as small mountain catchments. Although total discharge may not be very high, flood height can be considerable due to the narrow river channels and urban structures, and they can produce extraordinary damage, mainly along the coast, due to intensive urbanisation surrounding streams (known locally as "riera"). The use of weather radar to nowcast and monitor these cases is essential, as shown by Atencia et al. (2011) and Rigo and Llasat (2004).

- Type 2 or extended flash floods: these are associated with heavy rain sustained over several hours, and can produce catastrophic floods due to the higher than normal daily rainfall (usually more than $200 \mathrm{~mm}$ ) and the extensive area covered by the storm (usually $>2000 \mathrm{~km}^{2}$ ). These events usually occur in autumn, although some cases have also been recorded in spring and summer. It is possible to distinguish between two subcategories:

(i) Type 2a (FF) lasts less than $24 \mathrm{~h}$ and the maximum precipitation is usually recorded in less than $6 \mathrm{~h}$, producing flash floods along short watercourses but also in upland headwaters with intermediate-sized catchments $\left(50-2000 \mathrm{~km}^{2}\right)$. These flash floods have produced the highest number of casualties when they have affected flood-prone areas with high concentrations of people. Some examples already cited in the introduction are the event of September 1962 in the Besós catchment (Gaume et al., 2009), the flash flood of June 2000 known as the "Montserrat case", which affected the Llobregat catchment (Martín et al., 2007; Milelli et al., 2006) and, in another region, the 2011 Genoa case (Fiori et al., 2014).

(ii) Type 2b (EFF) lasts more than $24 \mathrm{~h}$ but generally less than four days. Although accumulated rainfall is usually between 200 and $400 \mathrm{~mm}$, values of more than $800 \mathrm{~mm}$ are possible. They can produce flash floods in different catchments, some of them tributaries to large, perennial rivers $\left(>2000 \mathrm{~km}^{2}\right)$ that start in the Pyrenees, and in some occasions causing major floods. Damage produced by catastrophic floods of this kind includes the total or partial destruction of infrastructure, power cuts, urban floods, agricultural and livestock losses, and, frequently, loss of human life. The November 1982 event that affected the north-east of Spain, Andorra and the south-east of France (Trapero et al., 2013), and the Gard event of September 2002, are an example (Braud et al., 2010; Milelli et al., 2006).

(iii) Type 3 or Extended Floods (EF): these are the least frequent type in this region. They are episodes that last a long time (one week or more) with relatively weak average rainfall intensity, although there may be peaks of high intensity within the overall distribution, giving rise to localised flash floods. Total precipitation is usually above $200 \mathrm{~mm}$, affecting an extended region and giving rise, occasionally, to floods in perennial rivers. Although not very frequent, they usually occur in winter and, occasionally, in spring. The floods recorded in Catalonia in January 1996 are a good example: over $200 \mathrm{~mm}$ rainfall in 10 days, but with some convective peaks that produced localised flash floods.

As shown in Fig. 3, the coastal region experiences the highest frequency of floods, mainly as a consequence of LFF in small streams and non-permanent rivers, while larger catchments like the Llobregat River are affected by EFF and EF. The analysis of the systematic period 1981-2010 (Llasat et al., 2014) shows that a total of 219 floods were recorded across the region: $11 \%$ of them have produced catastrophic damages, $53 \%$ were extraordinary, and the rest only produced minor damages and can be considered ordinary. The municipalities most affected by flash floods were those in the Maresme (Fig. 3) region, which recorded 105 floods (61\% of which were extraordinary and around $10 \%$ of which were catastrophic). The Maresme region is, made up of torrential rivers with non-permanent flow that cross the villages, known locally as "ramblas" or "rieras". As a consequence, they are ungauged basins, usually with no rain gauge data, where flash floods are estimated based on their impact. The highest frequency of floods in Catalonia is in the autumn, followed by the summer, although LFF are mainly concentrated in August and September. This seasonal distribution matches the distribution of convective events (Llasat, 2001; Llasat et al., 2007), and is aggravated in the coastal region, due to the population changes in the summer holidays and tourism.

\subsection{Flash floods trends}

The analysis of changing flash floods in Catalonia for some catchments in the last six centuries (Llasat et al., 2005; Barrera-Escoda and Llasat, 2015), and for the systematic period 1981-2010 (Llasat et al., 2014), does not show any trend in catastrophic floods when looking at the region as a whole. However, there is a positive trend in all cases when extraordinary floods are considered. For the period 1301-2012, a slight positive trend is also shown for catastrophic floods in the Coastal Basins, and, in 


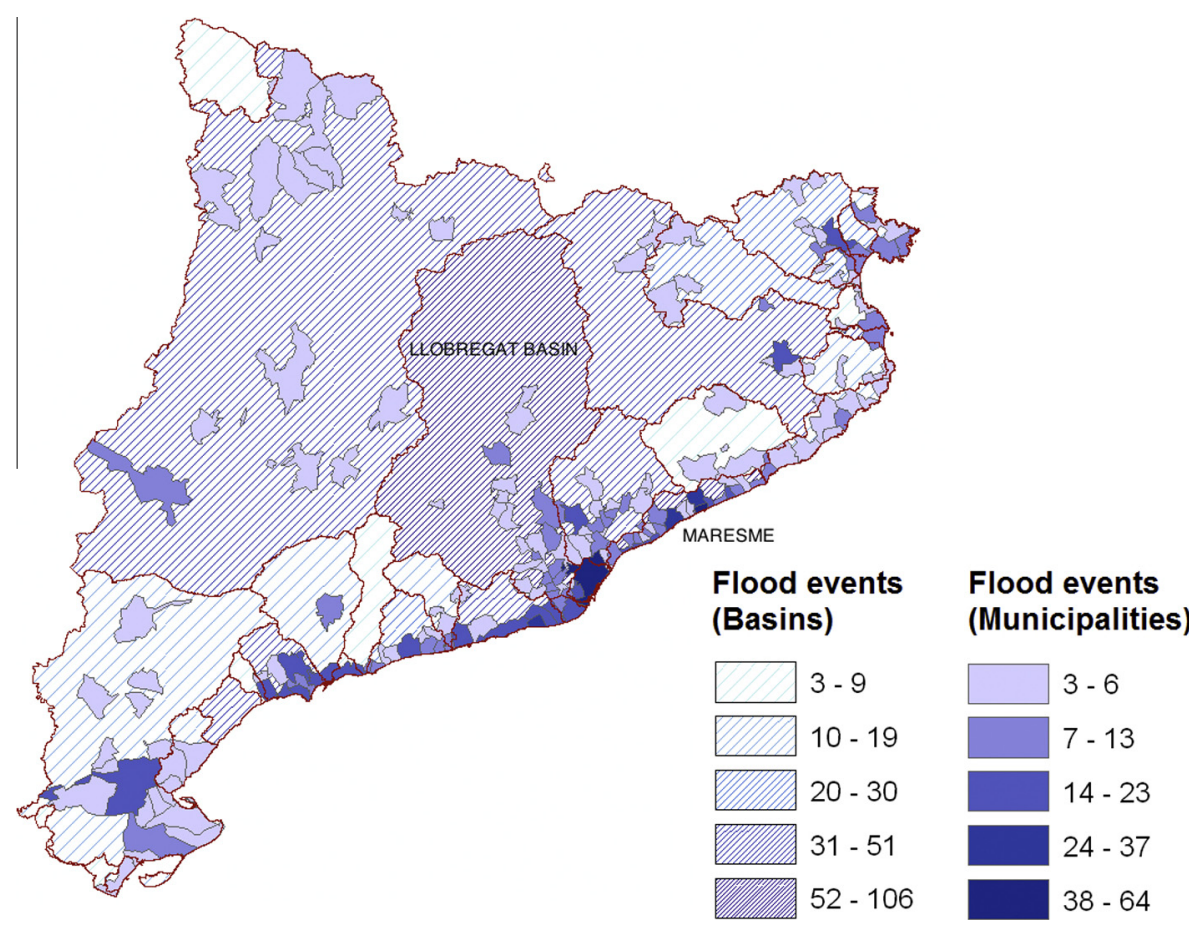

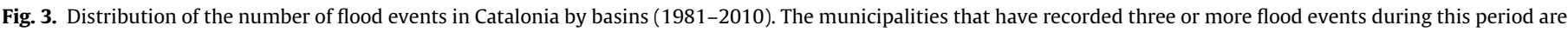
displayed.

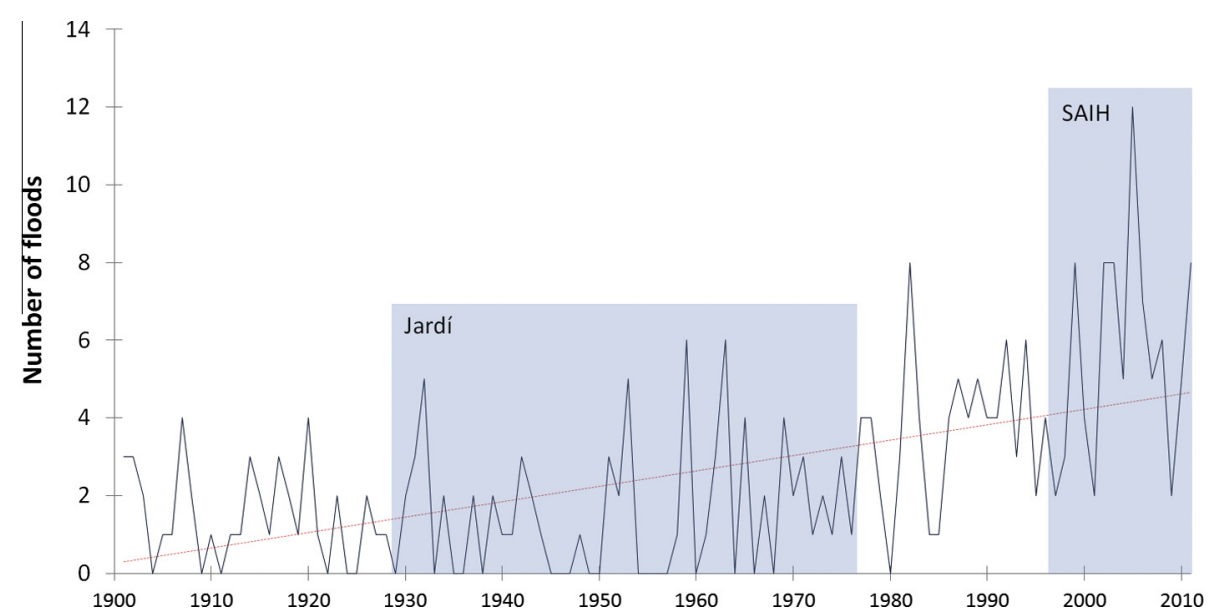

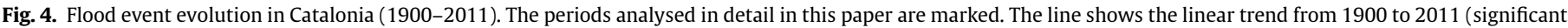
at $95 \%$ following Man Kendall method).

particular, for Barcelona (Barrera-Escoda and Llasat, 2015). Fig. 4 shows how flood events have evolved in Catalonia, from the period 1900-2011. Over this period, 216 flood events were extraordinary and 61 events caused catastrophic damage. When only the floods that affected the Internal Basins of Catalonia are considered, these figures decrease slightly to 209 and 58 floods, respectively. The positive trend observed can be due to the increase in related extraordinary events in terms of vulnerability and exposure changes, land-use changes, precipitation trends or the criteria used to record floods. A breakpoint has been detected in 1981, probably as a consequence of the systematic and careful research carried out day by day for any information related to floods after 1980, which might have an effect on this positive trend (it seems a statistical breakpoint because there is no corresponding societal or policy reason for such a breakpoint to have occurred). Nonetheless, both the 1900-1981 and 1981-2011 periods show a significant positive trend in extraordinary floods. The latter period also shows a positive trend in flash floods caused by precipitation that lasted less than 1 day. The seasonal analysis reveals that this trend is mainly due to a positive trend in the July-August-September period that is especially strong over the last decades: 0.3 flash flood events per decade and 0.8 flash flood events per decade (95\% significance) for the periods 1900-2011 and 1981-2011 respectively.

Figs. 5 and 6 show changes to floods in Catalonia for the 19281977 and 1996-2011 periods, respectively, for which sub-daily precipitation data is available. The first period does not show any trends, and 1959 was the year with the highest number of flood events (6); a total of 78 flood events (ordinary events are not included here) were recorded (69\% extraordinary, $31 \%$ catastrophic). $46 \%$ of the extraordinary events and $38 \%$ of the catastrophic events were caused by precipitation that lasted less than 1 day. Between 1996 and 2011, the total of 85 events showed 


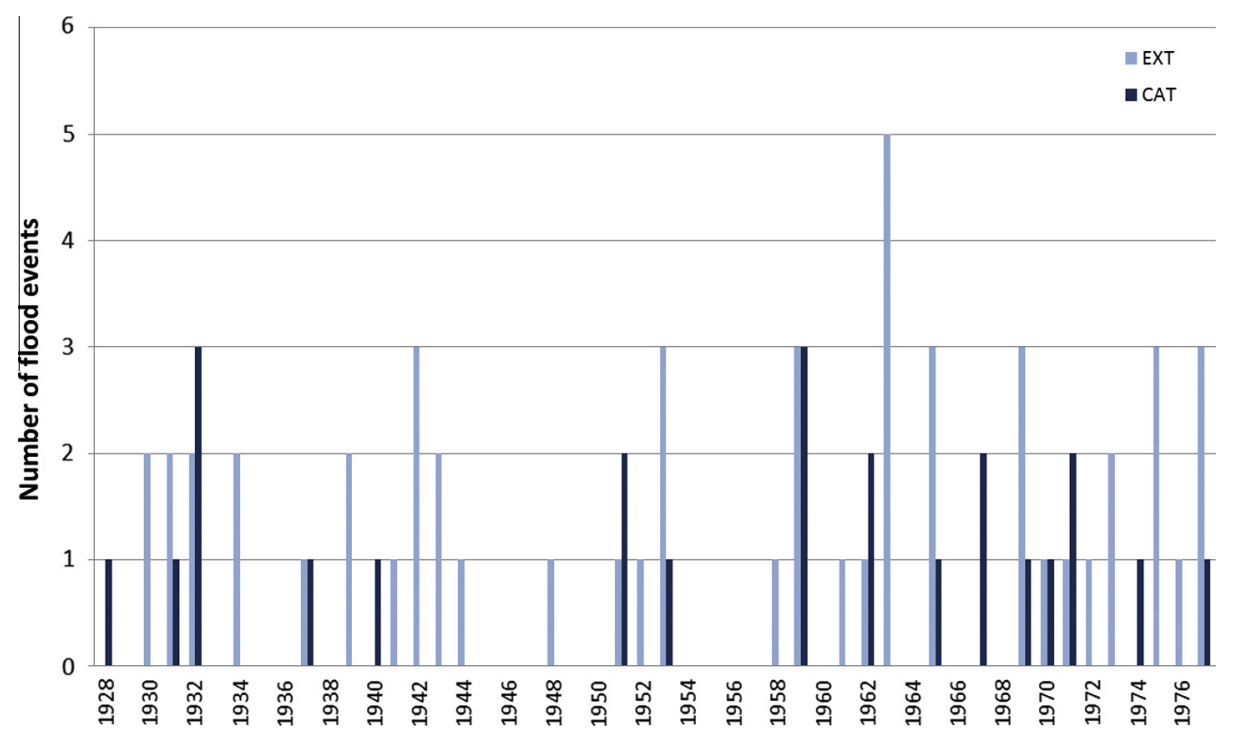

Fig. 5. Flood events evolution in Catalonia (1928-1977). EXT: Extraordinary flood events; CAT: Catastrophic flood events.

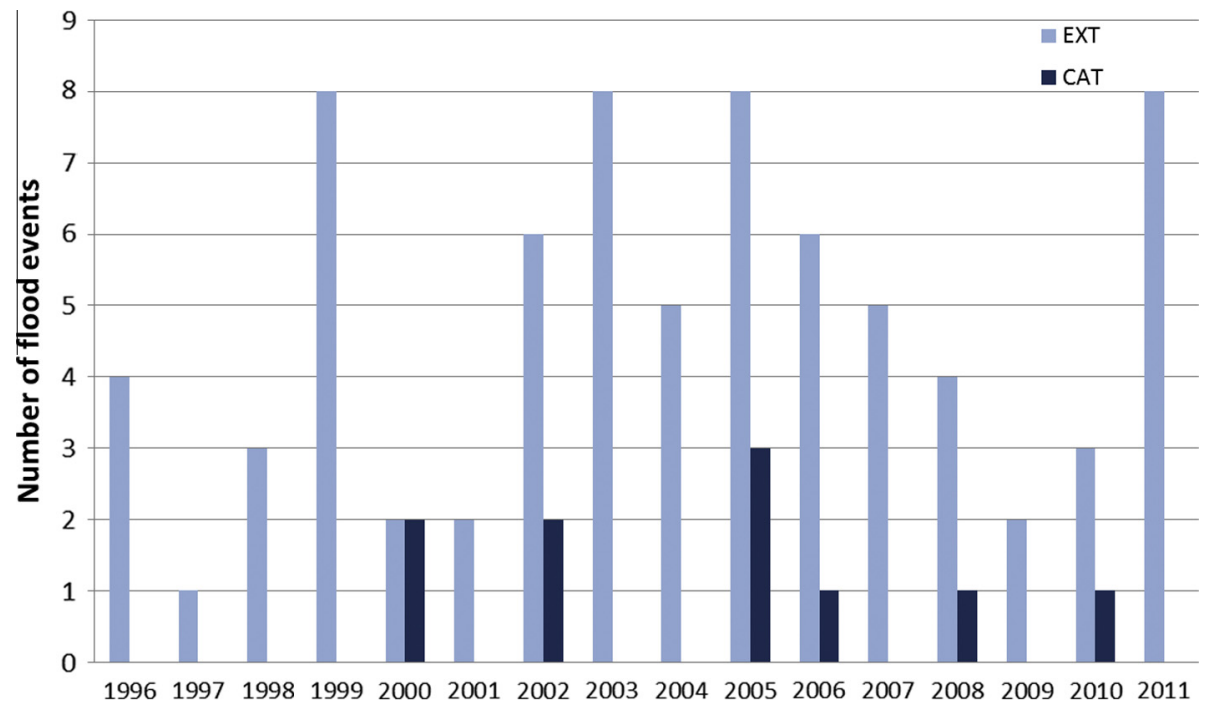

Fig. 6. Flood events evolution in Catalonia (1996-2011). EXT: Extraordinary flood events; CAT: Catastrophic flood events.

Table 2

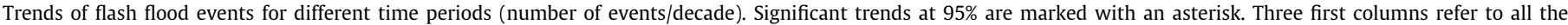
seasons.

\begin{tabular}{|c|c|c|c|c|c|c|c|}
\hline Period & Total & EXT & CAT & JAS total & JAS EXT & JJA totals & JJA EXT \\
\hline 1900-2011 & $0.60^{*}$ & $0.35^{*}$ & 0.03 & $0.30^{*}$ & $0.21^{*}$ & $0.20^{*}$ & $0.14^{*}$ \\
\hline $1900-1981$ & 0.02 & 0.08 & 0 & 0.06 & 0.07 & 0 & 0.04 \\
\hline $1981-2011$ & $1.10^{*}$ & $0.99^{*}$ & -0.11 & $0.80^{*}$ & $0.67^{*}$ & 0.55 & 0.42 \\
\hline 1926-1977 & 0.24 & 0.16 & 0.04 & 0.15 & 0.09 & 0.09 & 0.09 \\
\hline 1996-2011 & -1.40 & 0.82 & 0.46 & -0.73 & 0.46 & 0.1 & $1.07^{*}$ \\
\hline
\end{tabular}

JAS: July-August-September; JJA: June-July-August; CAT: catastrophic events; EXT: extraordinary events.

a higher frequency of intermediate events (75\% extraordinary flash floods) while $64 \%$ of them were caused by events that lasted less than 1 day. No significant trend was found due to the short length of the series and high interannual variability. However, it should be highlighted that in the Vallés and Maresme regions (R7, R9), 36 and 56 heavy precipitation and flash flood events were recorded, respectively, showing a positive trend for summer flash floods (Table 2).
The maximum annual discharge data series for the Ter River in Ripoll (Table 1), the Muga River in the Boadella dam, and the Llobregat River in Martorell were analysed for the period 1981-2011 (flow data series have not been available for this period on Gaià and Sau stations). No significant trend was found for the periods 1981-2011 and 1996-2011. The apparent disagreement with the trends found for flash flood events is not incoherent: the increase of extraordinary floods is mainly detected in small catchments. 


\section{Analysis of convective rainfall}

\subsection{Characterisation of convective precipitation}

In this work convective precipitation was identified in the SAIH network and using the Jardí rain gauge when rainfall intensity was over $35 \mathrm{~mm} / \mathrm{h}$ for 5 -min, and $1 \mathrm{~mm} / \mathrm{min}$ for a 1 -min series, respectively. The $\beta$ parameter was calculated following Eq. (1) and the criteria used to define convective precipitation during any rainfall episode follows the classification made by Llasat (2001). The definition of a rainfall episode is quite subjective, but we will use the definition previously used by Llasat et al. (2007). When using a single rain gauge, it is possible to distinguish between two different episodes when more than one hour elapses between each episode without any rainfall; when looking at the entire region covered by the SAIH network, the proposed time period without any precipitation is around three hours. A rainfall episode is classified as convective one when a minimum of one rain gauge has a value of $\beta>0$.

The results for the long data series for Barcelona show that convective precipitation was responsible for $18 \%$ of total annual precipitation. Convective precipitation was mainly recorded between August and October, although the bimodal distribution of days with convective precipitation shows a main peak in early autumn and a secondary peak in spring (Fig. 7). The largest total number of convective episodes occurred in the autumn, although the largest percentage of the total occurred in August with just over $18 \%$. $8 \%$ of the rainfall episodes (one meteorological event associated with precipitation may have different rainfall episodes or "storms", using the hydrological term) were convective and caused $37 \%$ of total annual precipitation. Strongly convective episodes usually lasted less than one hour, and mainly occurred in summer; $55 \%$ of them exceeded the threshold of a 5-min intensity of $125 \mathrm{~mm} / \mathrm{h}$. Moderately convective episodes increased throughout the year from winter to autumn, when they lasted up to five hours, and $63 \%$ of them recorded intensities above $75 \mathrm{~mm} / \mathrm{h}$. Finally, slightly convective rainfall episodes occurred throughout the year, mainly in the winter; in spite of their predominantly stratiform character, $41 \%$ of these episodes were over the 5 -min threshold of $75 \mathrm{~mm} / \mathrm{h}$. In terms of the contribution of convective precipitation to daily precipitation for convective days, the

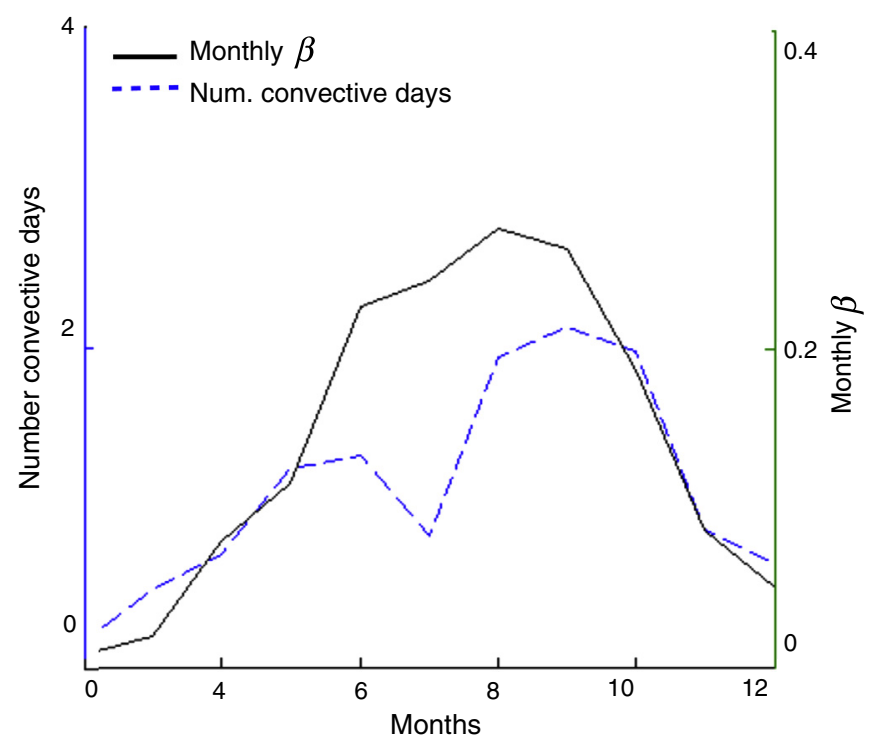

Fig. 7. Monthly distribution of the number of convective days and $\beta$ value for the Jardí raingauge, Fabra Observatory. (1928-1977). maximum levels were recorded in July with an average of $40 \%$, although this percentage rises in some cases to over $70 \%$.

When the analysis covers the entire region, convective rainfall episodes represent $17 \%$ of the total, and $90 \%$ of total precipitation. If only the events for which the accumulated rainfall is above $35 \mathrm{~mm}$ are considered, these percentages rise to $92 \%$ and $95 \%$, respectively. On average, $13 \%$ of the latter episodes are slightly convective, $47 \%$ are moderately convective, and $40 \%$ are strongly convective. Following Llasat et al. (2007), the chosen region can be divided into a set of eight homogeneous sub-regions based on their climatic convective features (Fig. 2). The regions on the central coast (R3 and R7) have the greatest annual contribution to convective precipitation with values above $30 \%$ of the total annual rainfall (50\% if we refer to the May to November period). Nevertheless, the region with the highest contribution of strongly convective rainfall episodes is in the north-east (R1), with over $20 \%$ of convective episodes. All these features will determine the temporal and spatial distribution of flash floods, as well as in their impact, as over 70\% of the population of Catalonia lives in these regions.

A study of the convective episodes from all the available 5-min precipitation gauges in the SAIH network over periods ranging from 11 to 14 years between 1996 and 2011, showed that $\beta$ thresholds 0.30 and 0.80 can be associated with, respectively, percentiles 25 and 90 (see Table 3 ). This is coherent with the classification of the slightly convective $(0<\beta<0.3)$ and strongly convective episodes $(0.8<\beta<1.0)$ calculated initially using the Jardí data series.

Fig. 8 shows the distribution of the most representative ETCCDI related to precipitation in Catalonia, calculated from Spain02. Following the previous discussion on convective features and this figure, there are two regions that are particularly concerned with intense precipitation: the first one is the North-east (R1 and R2), where the highest level of precipitation over a five-day period (RX5DAY) and the Simple Daily precipitation Intensity Index or average precipitation per day (SDII) show the highest values. This region usually records the maximum daily precipitation, and the return period for daily values above $200 \mathrm{~mm}$ is the lowest in all the Internal Basins of Catalonia (Casas et al., 2010). The second is the Southern region (R8), where thunderstorms are more frequent. The fact that the central coast, where there is the highest frequency of flash floods (Llasat et al., 2014), does not show any particular features corresponding to the ETCCDI, points to the importance of using sub-daily precipitation scales.

Given the above, two stations were chosen to represent the North-east region in this paper: Boadella (R1) and Sau (R2) (Fig. 2), located in the Muga and the Llobregat basins, respectively (Table 1). Although both rivers have their sources in the north-east of the Pyrenees, the Sau data series shows a unimodal distribution of convective precipitation and number of convective days throughout the year, with the highest values in July and August $(\beta>0.3)$, respectively (Fig. 9a). On the other hand, Boadella (Fig. 9b) shows the maximum contribution of convective precipitation on September and August $(\beta>0.2)$. This small seasonal difference reflects the major impact of summer thunderstorms and rainfall to the former, associated with the typical distribution of precipitation in the Pyrenees. Meanwhile, Boadella is most affected by the organised convective systems that develop near the coast in autumn, and its closer proximity to the sea.

Table 3

Percentile distribution of $\beta$ values for convective episodes in the Internal Basins of Catalonia.

\begin{tabular}{lllll}
\hline Percentiles & 25 & 50 & 75 & 90 \\
\hline Mean (median) & $0.32(0.31)$ & $0.50(0.50)$ & $0.69(0.70)$ & $0.84(0.85)$ \\
Standard Dev. & 0.04 & 0.05 & 0.07 & 0.07
\end{tabular}



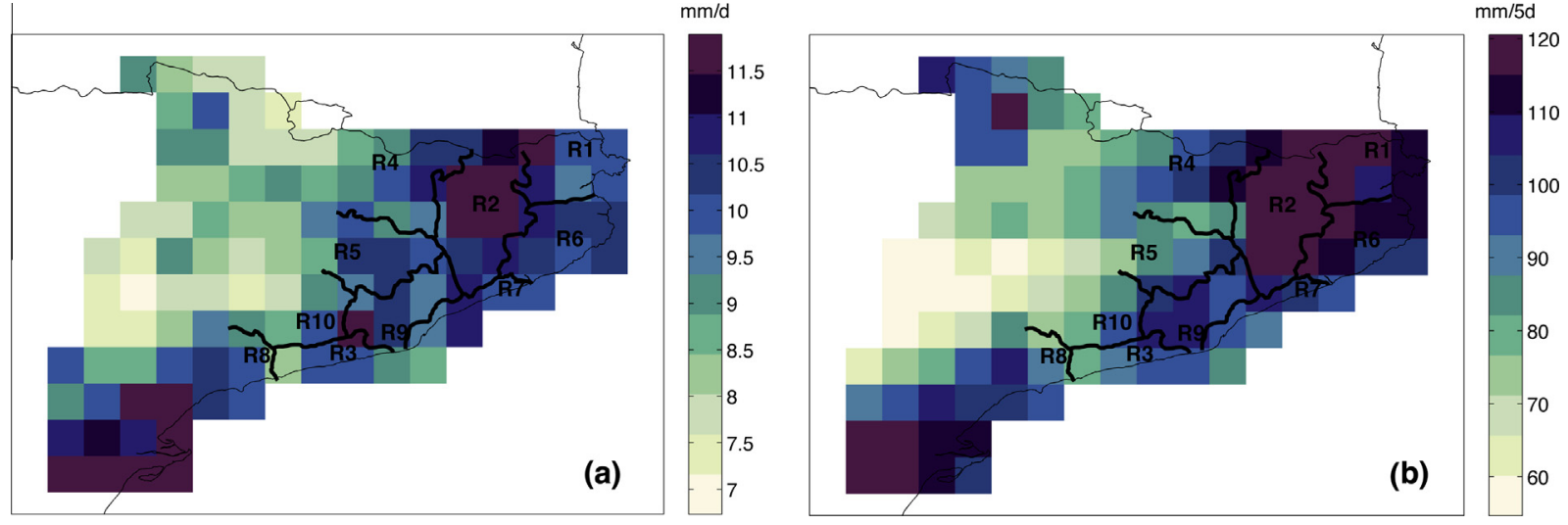

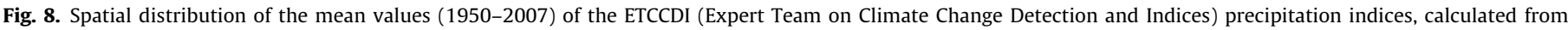
SPAIN02: (a) SDII (mm/d); (b) RX5DAY ( $\mathrm{mm} / 5$ days).
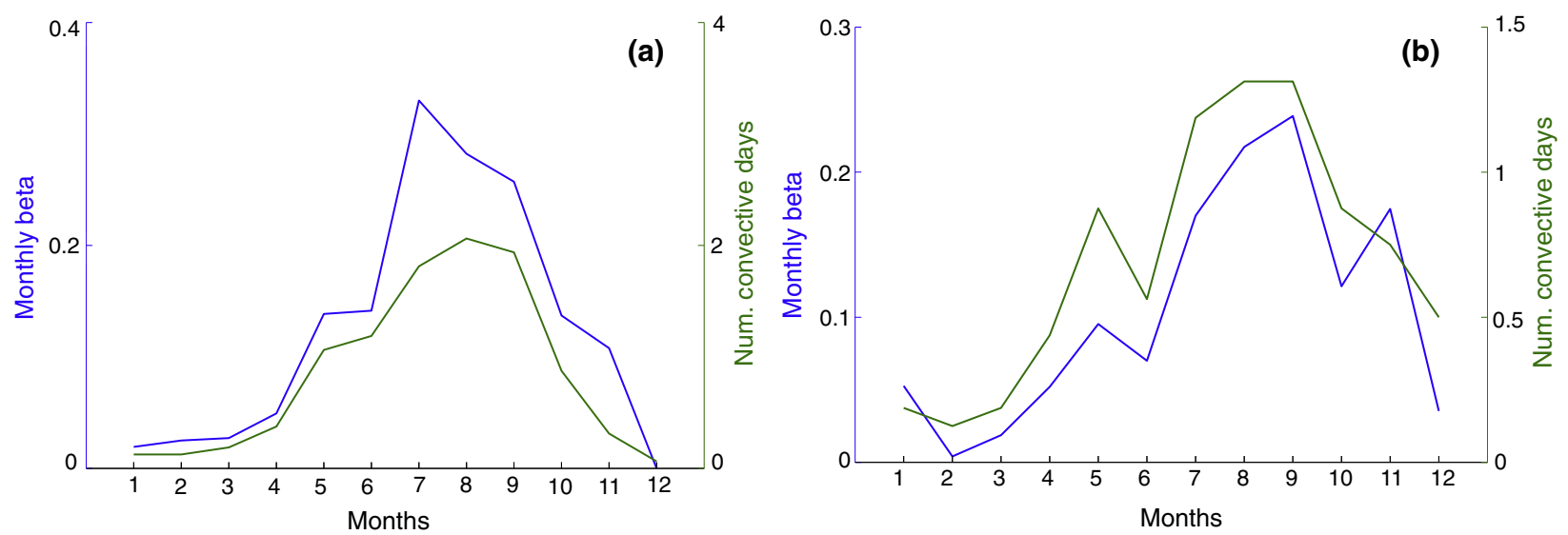

Fig. 9. Monthly distribution of the number of convective days and $\beta$ value for two raingauges (a) Sau; (b) Boadella (1996-2011).

Central and southern regions are represented by Terrassa (R7) and Gaià (R3) (Fig. 2). Their monthly changes in convective precipitation are similar to those one observed in the Jardí rain gauge, placed near Barcelona (Fig. 1), which reflects that more than $25 \%$ of August precipitation is convective and can be recorded in less than two days.

\subsection{Convective precipitation trends}

No general trends were observed for the period 1950-2007 on a regional scale, when considering the annual and seasonal regional values of all the ETCCDI indices and the different time windows along the entire analysed period. Only the length of consecutive dry days index (CDD) on an annual scale shows a locally coherent spatial trend pattern for part of the region. The SDII also shows a positive trend, mainly in the south of the region, but it is not significant at $95 \%$. These results can be complemented with those obtained by the Meteorological Service of Catalonia (Servei Meteorològic de Catalunya, 2014) for the longest data series for the Ebre (1905-2013) and Fabra (1914-2013) observatories, located in the south and centre of the region, respectively (Fig. 1). Among all the ETCCDI data related to precipitation, only the SDII shows a significant positive trend for the entire period in both observatories.

The analysis of the Jardí annual data series does not show any significant trends in the annual number of days with convective precipitation, neither in the number of days with slightly, moderately or strongly convective events that occurred during the 1928-1977 period (Fig. 10). A strong interannual variation is shown, with the highest annual value of 24 days with convective precipitation, in this period and 16 days, 15 days and 5 days, respectively, for the different categories. However, the results are different when trends for the selected stations for the 1996-2011 period are analysed. In fact, Gaià, Terrassa and Sau show a positive trend in the annual number of convective days. In Terrassa and Sau, annual precipitation and the annual time for which rainfall rate is above $35 \mathrm{~mm} / \mathrm{min}$ also showed an increase, while in Boadella a small decrease in annual $\beta$ and in the total time for convective precipitation was found. In the case of Terrassa, there is a relevant contribution showing a positive trend for strongly convective events $(\beta>0.8)$.

When the entire region is considered, a negative trend in the $\beta$ ratio on an annual scale can be observed in the north-east (R1, R6) while a positive trend is predominant in the central part of the region (R2, R5, R9, R7) as is shown in Fig. 11. This correlates with the observed trend of annual convective precipitation (and also of total precipitation). It should be highlighted that annual precipitation and the cumulated time for which it was recorded have increased in the Central part of the region, particularly in the case of heavy precipitation (Fig. 12). On the other hand, the annual number of convective days shows a significant predominantly negative trend, with the exception of regions R1 and R6 (Fig. 13). This points to an increase in convective precipitation in the central part of the region, concentrated in fewer days and fewer, although longer lasting, events. The seasonal analysis shows that this negative trend in the number of convective days, as well 


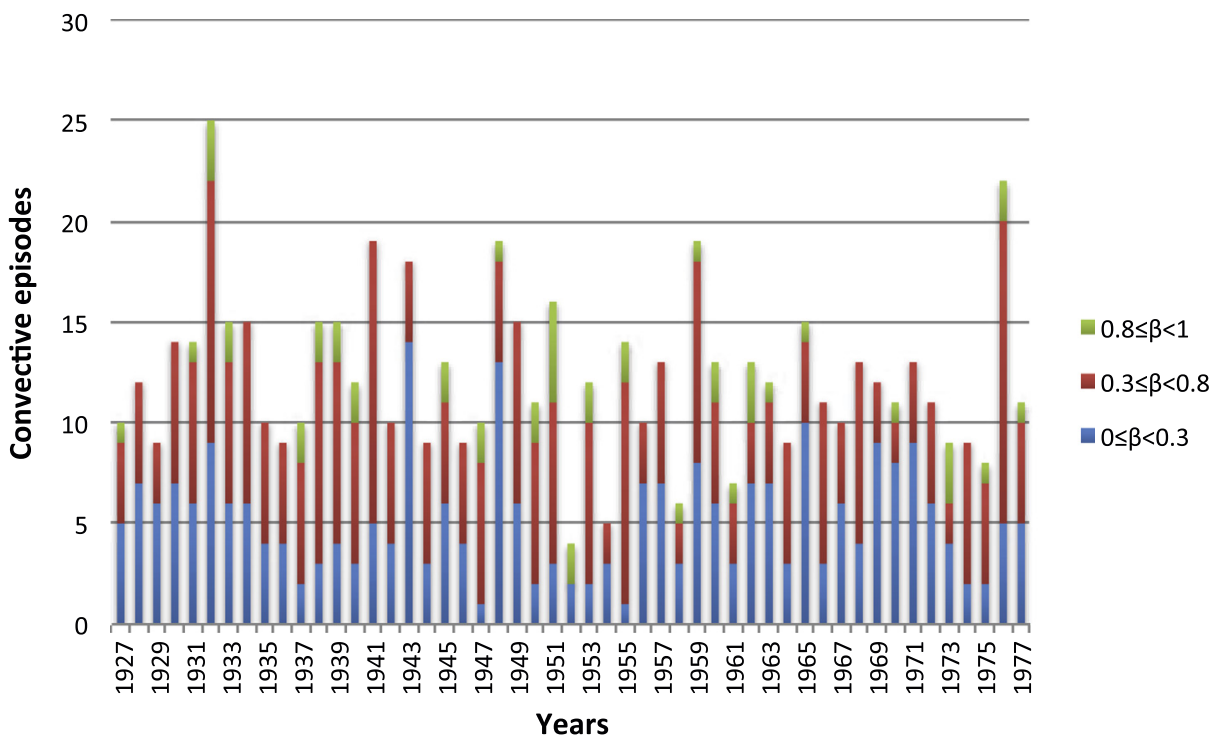

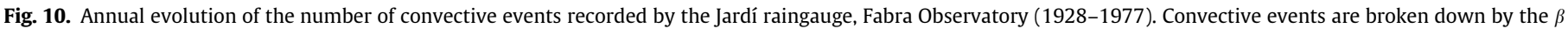
value associated with each.

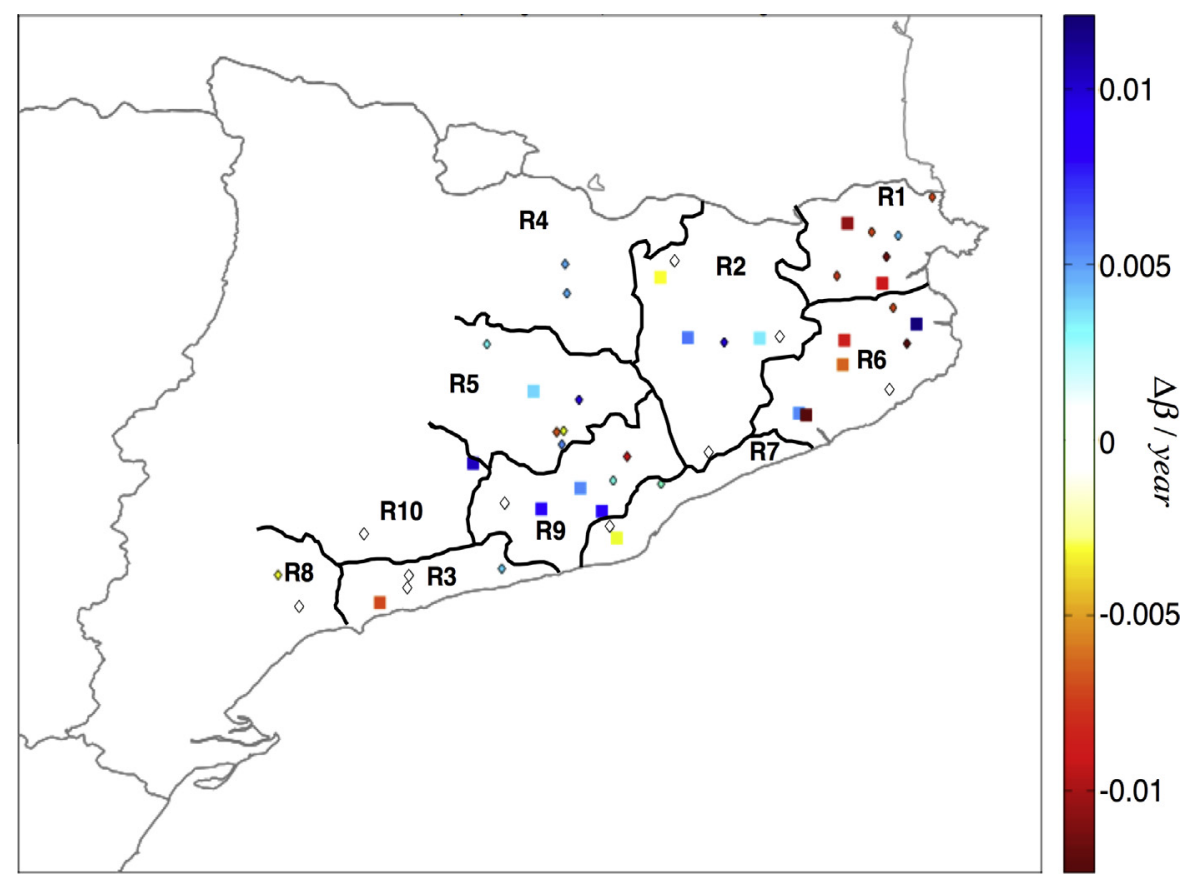

Fig. 11. Observed trend (5\% error level) in the mean annual value of $\beta$ parameter: square (significant trend), diamond (non significant trend).

as in the number of convective events in the centre, occurred during all the seasons, while the increase in the $\beta$ ratio is mainly due to the summer and autumn rainfall contribution. The trends are reversed in the north-east, where despite the increase in the number of convective days and convective events throughout the year, there are a strong decrease in convective precipitation and the time for which it is recorded, mainly in the summer but also in the autumn, associated to a significant decrease in total precipitation in both seasons. Finally, in the case of the south (R3, R8, R10), there is only a common negative trend in the annual number of convective days.

\section{Comparison between convective precipitation and floods}

The comparison between the number of annual flood events in Catalonia and annual $\beta$ parameter for the Jardí data series (1928-1977) shows a correlation of 0.22 (95\% significance). This number increases to 0.32 for the annual number of convective days and to 0.38 for events of a catastrophic nature. However, when the correlation is made using the catastrophic events that affected the Metropolitan Area of Barcelona between 1996 and 2011, it increases to 0.41 . Although these values are low, they point to a certain relationship, given that we are working on an annual scale 


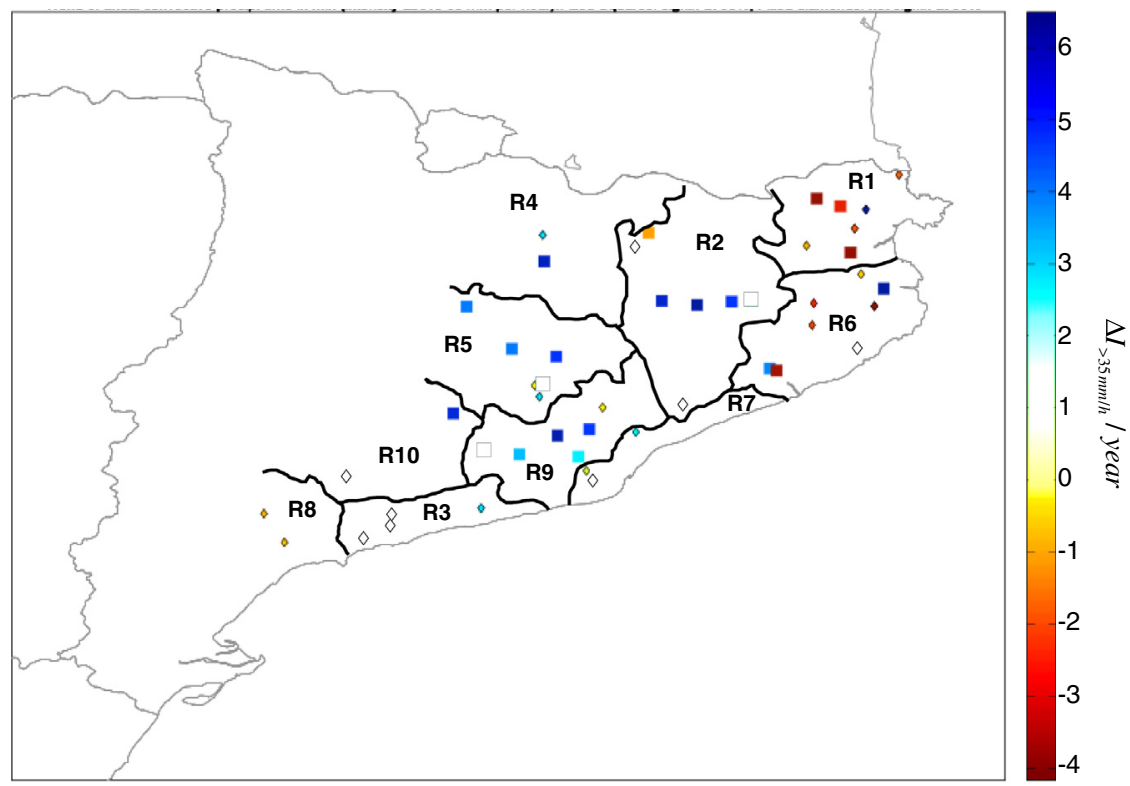

Fig. 12. Observed trend ( $5 \%$ error level) in the total annual time during which $5 \mathrm{~min}$ rainfall rate $>35 \mathrm{~mm} / \mathrm{h}$ : square (significant trend), diamond (non significant trend).

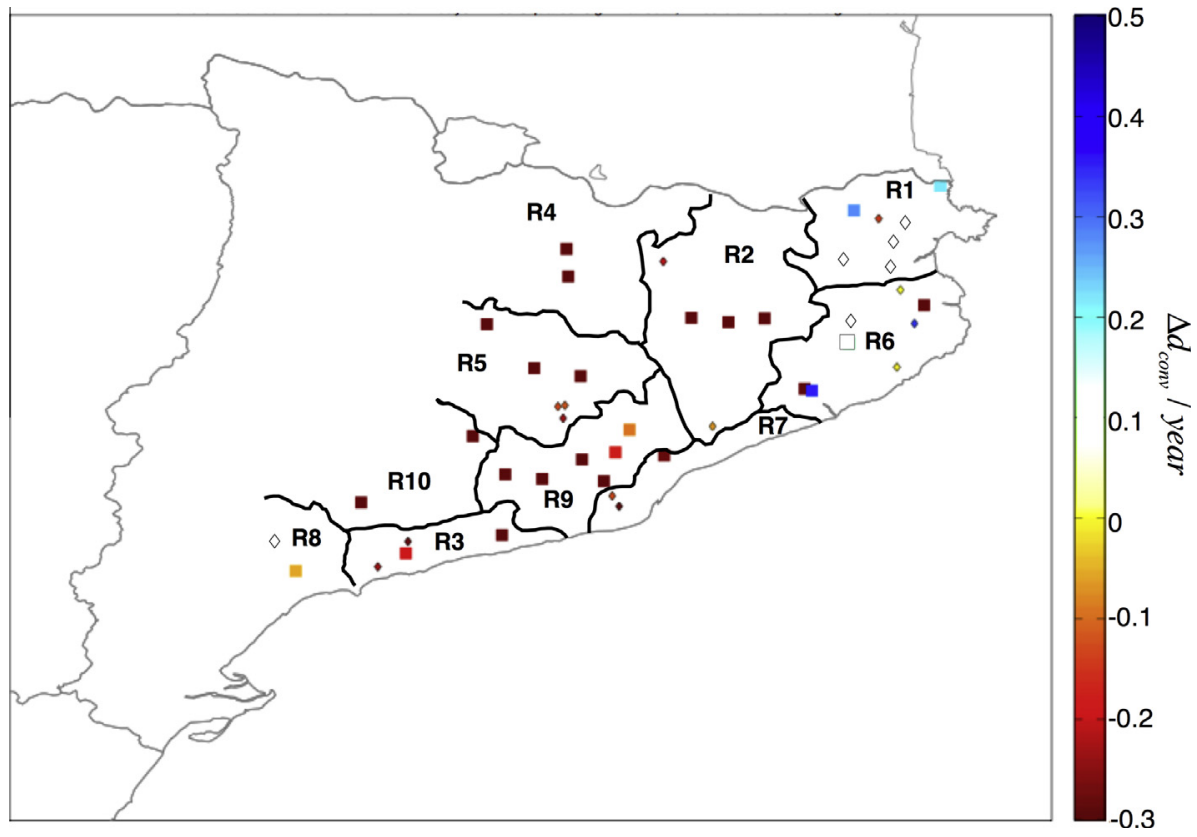

Fig. 13. Observed trend ( $5 \%$ error level) in the annual number of convective days: square (significant trend), diamond (non significant trend)

and the majority of convective events last less than one day. The features of the monthly flood series (usually made up of values of 0 and 1 ) have a bearing on finding any correlation with beta values.

This means the $\beta$ parameter is mainly useful to characterise flood events. Local flash floods (LFF) are usually associated to 'strongly convective events' $(\beta>0.8)$ and a considerable local instability, where convective precipitation is produced by 'isolated cells' or 'multicells' with limited horizontal extension (Rigo and Llasat, 2004). Type 2 events require convective instability with abundant warm and wet air feeding from low levels, and a mechanism that forces the air's ascent to release the potential instability or to destabilize the air column. Type 2a flash floods (FF) achieve a maximum hourly precipitation and are produced by 'strongly convective events', where convective rainfall is generally produced by 'multicells' or 'mesoscale convective systems'. In the case of Type $2 \mathrm{~b}$ events (EFF), peaks of heavy rainfall intensity and moderate but continuous rainfall are recorded successively, and consequently, they are 'moderate convective events' $(0.3<\beta<0.8)$. Finally Type 3 floods may be described as 'slight convective events' $(0<\beta<0.3)$, and are usually associated with convection embedded in stratiform rainfall. Finally, flood events characterised by $\beta=0$ would be associated to long-lasting, low-intensity stratiform precipitation, which would not cause any flash floods.

Tables 4 and 5 show the most significant catastrophic floods recorded during the 1929-1977 and 1996-2011 periods, respectively. The 10 June 2000 and 25 September 1962 floods are examples of FF events, while the other cases are examples of EFF. 
Table 4

Main catastrophic flood events that have produced flash floods, recorded between 1928 and 1977 in Catalonia.

\begin{tabular}{|c|c|c|c|c|c|c|}
\hline Date & Region & $\operatorname{Pmax}(\mathrm{mm})$ & $\operatorname{Qmax}\left(\mathrm{m}^{3} / \mathrm{s}\right)$ & Daily $\beta \max$ & Deaths & Damages M€ (2013) \\
\hline $17-19 / 10 / 1940$ & $\mathrm{R} 1, \mathrm{R} 2, \mathrm{R} 4$ & 743 (Camprodón,Ter) & 2350 (Sau, Ter River) & 0.56 & 90 & $>136$ \\
\hline $25 / 9 / 1962$ & R7, R9 & 250 (Martorelles, Besòs) & 1870 (Sant Adrià del Besòs, Besòs River) & 0.78 & 815 & $>533$ \\
\hline $19-23 / 9 / 1971$ & R1, R2, R6, R7, R9 & 639 (Figueres, Muga) 426 (St. Boi de Llobregat) & 3080 (Martorell, Llobregat River) & 0.34 & 19 & $>835$ \\
\hline
\end{tabular}

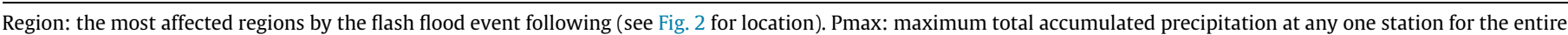

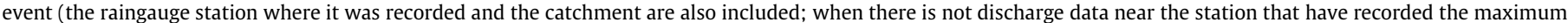

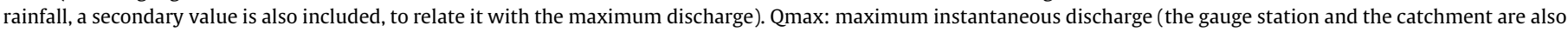

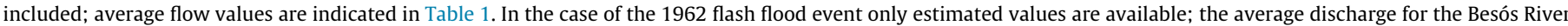

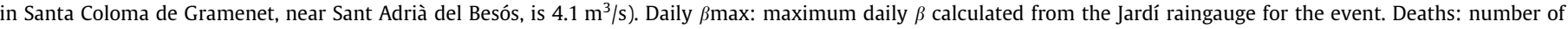
deaths in Catalonia (Spain). Damages: economic losses in millions of euros updated to 2013.

Table 5

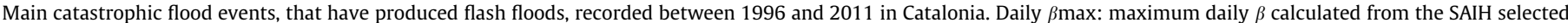

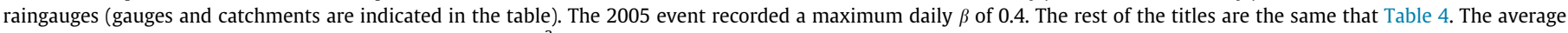
discharge for the Ter River in Torroella de Montgrí is $26.8 \mathrm{~m}^{3} / \mathrm{s}$. The asterisk means insured damages.

\begin{tabular}{|c|c|c|c|c|c|c|c|c|c|}
\hline \multirow[t]{2}{*}{ Date } & \multirow[t]{2}{*}{ Region } & \multirow[t]{2}{*}{$\operatorname{Pmax}(\mathrm{mm})$} & \multirow[t]{2}{*}{$\operatorname{Qmax}\left(\mathrm{m}^{3} / \mathrm{s}\right)$} & \multicolumn{4}{|l|}{ Daily $\beta \max$} & \multirow[t]{2}{*}{ Deaths } & \multirow{2}{*}{$\begin{array}{l}\text { Damages M€ } \\
\text { (2013) }\end{array}$} \\
\hline & & & & $\begin{array}{l}\text { Terrassa } \\
\text { (Llobregat) }\end{array}$ & $\begin{array}{l}\text { Gaià } \\
\text { (Gaià) }\end{array}$ & $\begin{array}{l}\text { Sau } \\
\text { (Ter) }\end{array}$ & $\begin{array}{l}\text { Boadellla } \\
\text { (Muga) }\end{array}$ & & \\
\hline $10 / 6 / 2000$ & R7, R9 & 257 (Collbató, Llobregat) & $\begin{array}{l}1400 \text { (Martorell, Llobregat } \\
\text { River) }\end{array}$ & 0.9 & 0 & 0 & 0.9 & 5 & $>90\left(38^{*}\right)$ \\
\hline $8-10 / 10 / 2002$ & R7, R9 & 174.1 (S. Joan Despí, Llobregat) & 211(PapiolRubí torrent) & 1.0 & 1.0 & 0 & 0 & 0 & $16^{*}$ \\
\hline $5-8 / 9 / 2005$ & $\begin{array}{l}\mathrm{R} 1, \mathrm{R} 6 \\
\mathrm{R} 7, \mathrm{R} 3\end{array}$ & 165 (Òdena, Llobregat) & $\begin{array}{l}561 \text { (Sant Joan Despí, Llobregat } \\
\text { River) }\end{array}$ & 0.8 & 0.8 & 0.9 & 0 & 2 & $>13$ \\
\hline $11-14 / 10 / 2005$ & R1, R6 & $\begin{array}{l}393.4 \text { (Castell d'Aro, Costa Brava } \\
\text { torrents) }\end{array}$ & $\begin{array}{l}238 \text { (Torroella de Montgrí, Ter } \\
\text { River) }\end{array}$ & 0 & 0 & 0 & 0 & 4 & $>53^{*}$ \\
\hline $12-14 / 9 / 2006$ & R7, R9, R3 & $\begin{array}{l}267.3 \text { (Constantí, Francolí) } 110.9 \\
\text { Cerdanyola, Besòs) }\end{array}$ & $\begin{array}{l}543 \text { (Sta. Coloma de Gramenet, } \\
\text { Besós River) }\end{array}$ & 1.0 & 1.0 & 0 & 0 & 1 & $>89\left(65^{*}\right)$ \\
\hline
\end{tabular}

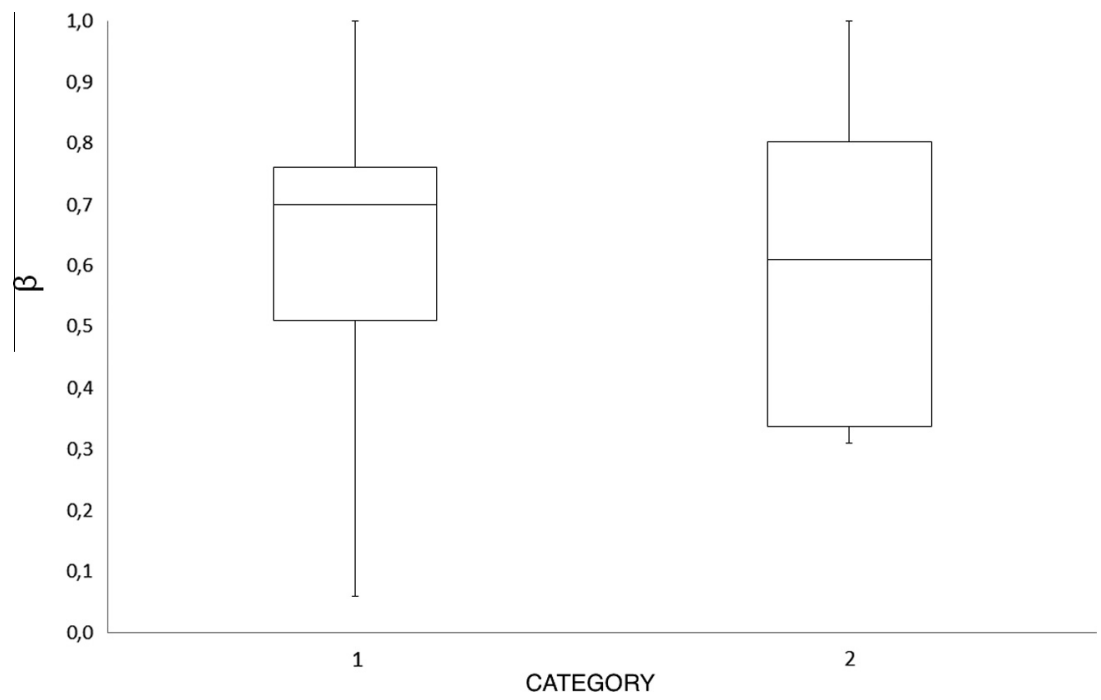

Fig. 14. Box plot of daily $\beta$ by flash flood categories: (1) extraordinary; (2) catastrophic.

The different $\beta$ values for the chosen regions corroborates the high spatial variability of convective precipitation. Although rainfall intensity did not reach $35 \mathrm{~mm} / \mathrm{h}$ in any of the four selected stations during the flood of October 2005, data from another station shows that it was moderately convective.

Fig. 14 shows the distribution of the maximum daily $\beta$ value for extraordinary and catastrophic flood events, aggregating both periods for which this parameter can be calculated. Despite the notable dispersion that is typical for this kind of heavy precipitation events, the results match the main features explained in the previous paragraph. Usually, extraordinary events are associated to LFF and the median $\beta$ shows a high degree of convective precipitation contribution ( $\beta=0.7$ ). The median $\beta$ decreases when it refers to catastrophic events $(\beta=0.6)$ because such events are longer and more extensive. Although accumulated convective precipitation can be very high, its relationship to total precipitation decreases. As the distribution shows, $25 \%$ of these catastrophic events have $\beta$ values higher than 0.8 (FF) while the longest events, making up $25 \%$ of this category, show $\beta$ values close to 0.3 (EFF). When looking at events that have last less than one day, none of them have shown a result where $\beta=0$ which means that all of them are convective. 


\section{Conclusions}

In the Mediterranean context of a steep coastal topography along with a dense infrastructure and population, it is very important to understand the evolution of sub-hourly precipitation events in the context of a changing climate. As the last decade was one of the warmest ever recorded (IPCC, 2013) in this paper we have taken a look at the evolution of convective precipitation on a 5 -min scale in a region representative of the north-west Mediterranean, which is characterised by yearly flash floods that occasionally produce catastrophic damage.

The introduction of the $\beta$ parameter, calculated using 1-min and 5 -min precipitation series, meant it was possible to determine the contribution of convective precipitation to any event for any time scale. The classification of flash flood events, proposed by Llasat (2001) on the basis of the analysis on 1-min precipitation series from the Jardí rain gauge, has been expanded here for the Internal Basins of Catalonia by adding 43 rain gauges with 5-min increments. The contribution of convective precipitation is above $50 \%$ for $75 \%$ of the extraordinary flash flood events, and it increases to $70 \%$ for $50 \%$ of them. They mainly occur in August, September and October and are usually local and short-term events caused by stationary thunderstorms. The median of this contribution for catastrophic flash flood events is $61 \%$, but it is always over $31 \%$ and is greater than $80 \%$ in $25 \%$ of cases. The latter events, which usually occur in autumn, are the most catastrophic, with accumulated precipitation values of over $200 \mathrm{~mm}$ for less than three hours. Multi-cellular (usually stationary 'convective trains') and mesoscale convective systems (MCS) are responsible for these heavy rains. Long-lasting extraordinary events with some peaks of convective precipitation and occasional flash floods may have $\beta$ values below 0.30 , although the sub-daily $\beta$ maximum may still be higher than 0.80 , and they are usually recorded in winter and spring.

An interesting finding is the positive trend observed for extraordinary flash flood events for the 1900-2011 period, which corroborates previous findings showed in the literature. This trend is mainly associated which the events recorded in the centre (both coastal and inland), where the majority of the population lives. It is particularly relevant in the summer (July-August-September), when an increase of 8 events/decade has been found. An initial theory was to consider that an increase in exposition and vulnerability could have been the cause, as the population density in flash flood prone areas has increased considerably. This problem is aggravated in the summer, when some villages near the sea can go from a population of less than 1000 inhabitants to over 100,000 inhabitants. However, this study shows that there is an overall increase in both total and convective precipitation, an increase in the beta parameter and a decrease in the number of convective days and rainfall episodes, pointing towards more concentrated and intense convective events. Although less important, the autumn season shows a similar pattern, mainly for September. These results are coherent with the hypothesis formulated by the IPCC (2012, 2014) about the increase in torrential events and the role played by vulnerability and exposure changes.

However, these results cannot be extended to the entire region. The north-east shows a negative precipitation trend as well as an increase in the number of convective events, but they are shorter-lasting and less intense, leading to a decrease in convective precipitation and in the $\beta$ parameter. Although this last finding would affect all the seasons, summer, followed by autumn, are the seasons that are most affected, due to the decrease in precipitation and convective precipitation. Given that any significant trend shown was in terms of the number of flash floods that have affected the region, the increase in exposure and vulnerability factors could be considered a cause. These results are also consistent with future scenarios, taken from the report on future scenarios on water resources in Spain, showing that the north-east of Catalonia will experience the biggest decreases (CEDEX, 2011).

\section{Acknowledgements}

This paper was written under the framework of the International HYMEX project and the Spanish HOPE (CGL2014-52571-R) project. We would like to thank the "Agència Catalana de l'Aigua" and the "Real Academia de Ciencias y Artes de Barcelona" for the SAIH and Jardí data provided, respectively. This work was partially funded by the Project of Interest 'NextData' of the Italian Ministry for Education, University and Research. We thank the anonymous reviewers whose comments greatly helped us improve the presentation of the results.

\section{References}

ACA, 2009. Aigua i canvi climàtic. Diagnosi del impactes previstos a Catalunya Generalitat de Catalunya, 332 pp.

Atencia, A., Mediero, L., Llasat, M.C., Garrote, L., 2011. Effect of radar rainfall time resolution on the predictive capability of a distributed hydrologic model Hydrol. Earth Syst. Sci. 15, 3809-3827.

Aulet, J., Cabezas, S., Clua, F., Fernández, A., Ferrer, M., Frigola, E., Llasat, M.C. Màrquez, M., Masó, A., Masó, O., Mauri, F., Plans, L., Pont, F., L.L. Puig, 2012 L'aiguat del 1962, 50 anys després. Editorial Amfora, Fundacio Torre del Palau, Els Llibres de Terrassa, Ajuntament de Terrassa (Ed.).

Barrera, A., Llasat, M.C., Barriendos, M., 2006. Estimation of the extreme flash flood evolution in Barcelona county from 1351 to 2005. Nat. Hazards Earth Syst. Sci. 6, 505-518.

Barrera-Escoda, A., Llasat, M.C., 2015. Evolving flood patterns in a Mediterranean region (1301-2012) and climatic factors - the case of Catalonia. Hydrol. Earth Syst. Sci. 19, 465-483.

Barriendos, M., Coeur, D., Lang, M., Llasat, M.C., Naulet, R., Lemaitre, F., Barrera, A. 2003. Stationarity analysis of historical flood series in france and spain (14th20th centuries). Nat. Hazards Earth Syst. Sci. 3, 583-592.

Borga, M., Gaume, E., Creutin, J.D., Marchi, L., 2008. Surveying flash flood response: gauging the ungauged extremes. Hydrol. Process. 22 (18), 3883-3885.

Braud, I., Roux, H., Anquetin, S., Maubourguet, M.M., Manus, C., Viallet, P., Dartus, D. 2010. The use of distributed hydrological models for the Gard 2002 flash flood event: analysis of associated hydrological processes. J. Hydrol. 394 (1-2), 162 181.

Braud, I., Bouvier, C., Branger, F., Delrieu, G., Le Coz, J., Nord, G., Vandervaere, J.-P., Anquetin, S., Adamovic, M., Andrieu, J., Batiot, C., Boudevillain, B., Brunet, P., Carreau, J., Confoland, A., Didon-Lescot, J.-F., Domergue, J.-M., Douvinet, J. Dramais, G., Freydier, R., Gérard, S., Huza, J., Leblois, E., Le Bourgeois, O., Le Boursicaud, R., Marchand, P., Martin, P., Nottale, L., Patris, N., Renard, B., Seidel J.-L., Taupin, J.-D., Vannier, O., Vincendon, B., Wijbrans, A., 2014. Multi-scale hydrometeorological observation and modelling for flash flood understanding. Hydrol. Earth Syst. Sci. 18, 3733-3761.

Brázdil, R., Chromá, K., Reznícková, L., Valášek, H., Dolák, L., Stachon, Z., Soukalová, E., Dobrovolný, P., 2014. The use of taxation records in assessing historica floods in South Moravia, Czech Republic. Hydrol. Earth Syst. Sci. 18, 3873-3889.

Burgueño, A., Austin, J., Vilar, E., Puigcerver, M., 1987. Analysis of moderate and intense rainfall rates continuously recorded over half a century and influence on microwave communications planning and rain-rate data acquisition. IEEE Trans. Commun. 35 (4), 382-395.

CEDEX, 2011. Evaluación del Impacto del Cambio Climático en los recursos hídricos en régimen natural. Resumen ejecutivo. Encomienda de Gestión de la Dirección General del Agua (MARM) al CEDEX para el estudio del cambio climático en los recursos hídricos y las masas de agua.

Casas, M., Rodríguez, R., Prohom, M., Gázquez, A., Redaño, A., 2010. Estimation of the probable maximum precipitation in Barcelona (Spain). Int. J. Climatol. 31 (9), 1322-1327.

Delrieu, G., Nicol, J., Yates, E., Kirstetter, P.E., Creutin, J.D., Anquetin, S., Obled, Ch., Saulnier, G.M., Ducrocq, V., Gaume, E., Payrastre, O., Andrieu, H., Ayral, P.A., Bouvier, Ch., Neppel, L., Livet, M., Lang, M., Parent du-Châtelet, J., Walpersdorf, A., Wobrock, W., 2005. J. Hydrometeorol. 6, 34-52.

Dutton, E.J., Dougherty, H.T., 1979. Year-to-year variability of rainfall for microwave applications in the U.S.A. IEEE Trans. Comm. COM-27 5, 829-832.

Fiori, E., Comellas, A., Molini, L., Rebora, N., Siccardi, F., Gochis, D.J., Tanelli, S., Parodi, A., 2014. Analysis and hindcast simulations of an extreme rainfall event in the Mediterranean area: The Genoa 2011 case. Atmos. Res. 138, 13-29.

Garambois, P.A., Larnier, K., Roux, H., Labat, D., Dartus, D., 2014. Analysis of flash flood-triggering rainfall for a process-oriented hydrological model. Atmos. Res. 137, 14-24.

Garrote, L., Bras, R.L., 1995a. A distributed model for real-time flood forecasting using digital elevation models. J. Hydrol. 167, 279-306. 
Garrote, L., Bras, R.L., 1995b. An integrated software environment for real-time use of a distributed hydrologic model. J. Hydrol. 167, 307-326.

Gaume, E., Borga, M., 2008. Post-flood field investigations in upland catchments after major flash floods: proposal of a methodology and illustrations. J. Flood Risk Manage. 1, 175-189.

Gaume, E., Bain, V., Bernardaza, P., Newinger, O., Barbuc, M., Bateman, A. Blaskovicov́a, L., Blöschl, G., Borga, M., Dumitrescu, A., Daliakopoulos, I., Garcia, J., Irimescu, A., Kohnova, S., Koutroulis, A., Marchi, L., Matreata, S., Medina, V., Preciso, E., Sempere-Torres, D., Stancalie, G., Szolgay, J., Tsanis, J., Velasco, D., Viglione, A., 2009. A compilation of data on European flash floods. J. Hydrol. 367, 70-78.

Giannoni, F., Roth, G., Rudari, R., 2000. A semi-distributed rainfall-runoff model based on a geomorphologic approach. Phys. Chem. Earth B. 25, 665-671.

Glaser, R., Riemann, D., Schönbein, J., Barriendos, M., Brázdil, R., Bertolin, C., Camuffo, D., Deutsch, M., Dobrovolný, P., van Engelen, A., Enzi, S., Halícková, Koening, S.J., Kotyza, O., Limanówka, D., Macková, J., Sghedoni, M., Martin, B., Himmelsbach, I., 2010. The variability of European floods since AD 1500. Climat. Change 101, 235-256.

Hall, J., Arheimer, B., Borga, M., Brázdil, R., Claps, P., Kiss, A., Kjeldsen, T.R., Kriaučiūnienè, J., Kundzewicz, Z.W., Lang, M., Llasat, M.C., MacDonald, N., McIntyre, N., Mediero, L., Merz, B., Merz, R., Molnar, P., Montanari, A., Neuhold, C., Parajka, J., Perdigão, R.A.P., Plavcová, L., Rogger, M., Salinas, J.L., Sauquet, E., Schär, C., Szolgay, J., Viglione, A., Blöschl, G., 2014. Understanding flood regime changes in Europe: a state of the art assessment. Hydrol. Earth Syst. Sci. 18, 2735-2772.

Hally, A., Caumont, O., Garrote, L., Richard, E., Weerts, A., Delogu, F., Fiori, E., Rebora, N., Parodi, A., Mihalović, A., Ivković, M., Dekić, L., van Verseveld, W., Nuissier, O., Ducrocq, V., D’Agostino, D., Galizia, A., Danovaro, E., Clematis, A., 2015. Hydrometeorological multi-model ensemble simulations of the 4 November 2011 flash flood event in Genoa, Italy, in the framework of the DRIHM project. Nat. Hazards Earth Syst. Sci., 15, 537-555.

Herrera, S., Fita, L., Fernandez, J.M., Gutierrez, J., 2010. Evaluation of the mean and extreme precipitation regimes from the ENSEMBLES regional climate multimodel simulations over Spain. J. Geophys. Res. 115, D21117.

Herrera, S., Gutiérrez, J.M., Ancell, R., Pons, M.R., Frías, M.D., Fernández, J., 2012 Development and analysis of a 50-year high resolution daily gridded precipitation dataset over Spain (Spain02). Int. J. Climatol. 32 (1) 74-85.

IPCC, 2012. Managing the risks of extreme events and disasters to advance climate change adaption (SREX). Intergovernmental Panel on Climate Change. Cambridge University Press, Cambridge, p. 582.

IPCC, 2013. Climate Change 2013: The Physical Science Basis, in: Contribution of Working Group I to the Fifth Assessment Report of the Intergovernmental Panel on Climate Change, Cambridge University Press, Cambridge, 1535 pp.

IPCC, 2014. Climate Change 2014: Impacts, Adaptation, and Vulnerability, IPCC Working Group II Contribution to the Fifth Assessment Report of the Intergovernmental panel on climate change <http://www.ipcc.ch/report/ar5/ wg $2 />$.

Jansà, A., Genovés, A., Picornell, M.A., Campins, J., Riosalido, R., Carretero, O., 2001. Western Mediterranean cyclones and heavy rain. Part II: Statistical approach. Meteorol. Appl. 8, 43-56.

Jansa, A., Alpert, P., Arbogast, P., Buzzi, A., Ivancan-Picek, B., Kotroni, V., Llasat, M.C., Ramis, C., Richard, E., Romero, R., Speranza, A., 2014. MEDEX: a genera overview. Nat. Hazards Earth Syst. Sci. 14, 1965-1984.

Lafore, J.P., Stein, J., Asencio, N., Bougeault, P., Ducrocq, V., Duron, J., Fischer, C., Héreil, P., Mascart, P., Masson, V., Pinty, J.P., Redelsperger, J.L., Richard, E., Vilà-Guerau de Arellano, J., 1998. The Meso-NH atmospheric simulation system, Part I: Adiabatic formulation and control simulations. Ann. Geophys. 16, 90-109.

Llasat, M.C., Puigcerver, M., 1992. Pluies extrêmes en Catalogne: influence orographique et caractéristiques synoptiques. Hydrol. Continentale 2, 99-115.

Llasat, M.C., 2001. An objective classification of rainfall events on the basis of their convective features. Application to rainfall intensity in the north-east of Spain. Int. J. Climatol. 21 (11), 1385-1400.

Llasat, M.C., Barriendos, M., Barrera, A., Rigo, T., 2005. Floods in Catalonia (NE Spain) since the 14th century. Climatological and meteorological aspects from historical documentary sources and old instrumental records. J. Hydrol. Applications of palaeoflood hydrology and historical data in flood risk analysis $313,32-47$.

Llasat, M.C., Ceperuelo, M., Rigo, T., 2007. Rainfall regionalization on the basis of the precipitation convective features using a raingauge network and weather radar observations. Atmos. Res. 83, 415-426.
Llasat, M.C., Llasat-Botija, M., Petrucci, O., Pasqua, A.A., Rosselló, J., Vinet, F., Boissier, L., 2013. Towards a database on societal impact of Mediterranean floods in the framework of the HYMEX project. Nat. Hazards Earth Syst. Sci. 13, 1-14.

Llasat, M.C., Marcos, R., Llasat-Botija, M., Gilabert, J., Turco, M., Quintana, P., 2014. Flash flood evolution in North-Western Mediterranean. Atmos. Res. 149, 230 243.

Llasat, M.C., Caumont, O., Flores, I., Garrote, L., Gilabert, J., Llasat-Botija, M., Marcos, R., Nuissier, O., Richard, E., Rigo, T., 2015. The 6 November 2011 flood event in Catalonia: analysis using the DRIHM infrastructure. In: Ferrari, E., Versace, P. (Eds.), Monitoring, Modelling and Early Warning of a Extreme Events Triggered by Heavy Rainfalls. Proceedings. pp. 167-164.

Lindstrom, G., Johansson, B., Persson, M., Gardelin, M., Bergstrom, S., 1997. Development and test of the distributed HBV-96 hydrological model. J. Hydrol. 201, 272-288.

Madsen, H., Lawrence, D., Lang, M., Martinkova, M., Kjeldsen, T., 2014. Review of trend analysis and climate change projections of extreme precipitation and floods in Europe. J. Hydrol. 519 (D), 3634-3650.

Marchi, L., Borga, M., Preciso, E., Gaume, E., 2010. Characterisation of selected extreme flash floods in Europe and implications for flood risk management. J. Hydrol. 394, 118-133.

Martín, A., Romero, R., Homar, V., de Luque, A., Alonso, S., Rigo, T., Llasat, M.C., 2007. Sensitivities of a flash flood event over Catalonia: a numerical analysis. Mon. Weather Rev. 135, 651-669.

MacDonald, N., 2014. Millennial scale variability in high magnitude flooding across Britain. Hydrol. Earth Syst. Sci. Discuss. 11, 10157-10178.

Mediero, L., Kjeldsen, T.R., MacDonald, N., Kohnova, S., Merz, B., Vorogushyn, S., Wilson, D., Alburquerque, T., Blöschl, G., Bogdanowicz, E., Castellarin, A., Hall, J., Kobold, M., Kriauciuniene, J., Lang, M., Madsen, H., Onusluel Gül, G., Perdigão, R. A.P., Roald, L.A., Salinas, J.L., Toumazis, A.D., Veijalainen, N., Óðinn Pórarinsson, 2015. Identification of coherent flood regions across Europe using the longest streamflow records. J. Hydrol. 528, 341-360.

Merz, B., Vorogushyn, S., Uhlemann, S., Delgado, J., Hundecha, Y., 2012. HESS Opinions "More efforts and scientific rigour are needed to attribute trends in flood time series". Hydrol. Earth Syst. Sci. 16, 1379-1387.

Milelli, M., Llasat, M.C., Ducroq, V., 2006. The cases of June 2000, November 2002 and September 2002 as examples of Mediterranean floods. Nat. Hazards Earth Syst. Sci. 6, 271-284.

Papagiannaki, K., Lagouvardos, K., Kotroni, V., 2013. A database of high-impact weather events in Greece: a descriptive impact analysis for the period 2001 2011. Nat. Hazards Earth Syst. Sci. 13, 727-736.

Puigcerver, M., Alonso, S., Lorente, J., Llasat, M.C., Redaño, A., Burgeño, A., Vilar, E., 1986. Preliminary aspects on rainfall rates in the north east of Spain. Theor. Appl. Climatol. 37, 97-109.

Rice, P.L., Holmberg, N.R., 1973. Cumulative time statistics of surface-point rainfall rates. IEEE Trans. Comm. COM-21 10, 1131-1136.

Rigo, T., Llasat, M.C., 2004. A methodology for the classification of convective structures using meteorological radar: application to heavy rainfall events on the Mediterranean coast of the Iberian Peninsula. Nat. Hazards Earth Syst. Sci. 4 59-68.

Seity, Y., Brousseau, P., Malardel, S., Hello, G., Benard, P., Bouttier, F., Lac, C., Masson, V., 2011. The AROME - France convective-scale operational model. Mon. Weather Rev. 139, 976-991.

Servei Meteorològic de Catalunya, 2014. Butlletí annual d'indicadors climàtics. Any 2013, 77 pp.

Skamarock, W.C., Klemp, J.B., Dudhia, J., Gill, D.O., Barker, D.M., Wang, W., Powers, J. G., 2005. A description of the advanced research WRF version 2 (No. NCAR/TN468+ STR). National Center For Atmospheric Research Boulder Co Mesoscale and Microscale Meteorology Div.

Sun, X., Lall, U., Merz, B., Viet Dung, N., Hierarchical Bayesian clustering for nonstationary flood frequency analysis: Application to trends of annual maximum flow in Germany. Water Resources Research, 51, 6586-6601.

Trapero, L., Bech, J., Duffourg, F., Esteban, P., Lorente, J., 2013. Mesoscale numerical analysis of the historical November 1982 heavy precipitation event over Andorra (Eastern Pyrenees). Nat. Hazards Earth Syst. Sci. 13, 2969-2990.

Turco, M., Llasat, M.C., 2011. Trends in indices of daily precipitation extremes in Catalonia (NE Spain), 1951-2003. Nat. Hazards Earth Syst. Sci. 11 (12), 32133226.

Turco, M., Quintana-Seguí, P., Llasat, M.C., Herrera, S., Gutiérrez, J.M., 2011. Testing MOS precipitation downscaling for ensembles regional climate models over Spain. J. Geophys. Res. 116, D18109.

Turco, M., Marcos, R., Quintana-Seguí, P., Llasat, M.C., 2014. Testing instrumental and downscaled reanalysis time series for temperature trends in NE of Spain in the last century. Reg. Environ. Change 14 (5), 1811-1823. 